\title{
Filologia mapy. Badanie dawnej kartografii metodą krytyki tekstu na przykładzie toponimii mapy Księstwa Połockiego S. Pachołowieckiego z 1580 roku $^{1}$
}

\begin{abstract}
The Philology of a Map. Studying Old Cartography Using the Method of Textual Criticism: the Case of Toponymy of the Map of the Principality of Polotsk by S. Pachołowiecki from 1580
\end{abstract}

The aim of this paper is to make an experimental application of textual criticism (the stemma method or Lachmann's method) in the analyses of early-modern maps. It is supposed to verify whether, and to what extent, the means developed by philologists to establish how texts were transmitted in medieval codices, can be applied to study the transmission of geographic knowledge on early-modern maps.

The author postulates that well-tried procedures should be used in studies of textual parts of old maps. They allow the formulation of filiation hypotheses. These procedures consist of collating extant texts and detecting mistakes that indicate, connect or divide individual branches of tradition.

1 Artykuł powstał $\mathrm{w}$ ramach projektu badawczego Narodowego Centrum Nauki Opus (nr 2014/15/B/HS2/01104) Związki literatury polskiej $i$ kartografii $w X V I-I$ pot. XVII $w$. 
The subject analysed is the toponymy appearing on the map Decriptio Ducatus Polocensis (The Description of the Principality of Polotsk) by Stanisław Pachołowiecki, engraved in Rome by Giovanni Battista Cavalieri in 1580 and on maps stemming from the same archetype. The author compiles a complete index of toponyms and hydronyms in transliteration and transcription, identifies them and provides the names in Belarussian, Russian and Polish. He also annotates each of them with a short topographic-historical description. Taking into consideration the state of the art regarding mutual relations between cartographic works drawing on Pachołowiecki's map of the Principality of Polotsk, he proposes a hypothetic stemma depicting the genealogy of the toponymic image of the Principality of Polotsk on $16^{\text {th }}$ and $17^{\text {th }}$ century maps. The analysis also includes four other relics: a manuscript map of Stanisław Sulimowski from 1580, a printed map Magni Ducatus Lithuanie, Livoniae et Moscoviae decriptio (A Description of the Grand Duchy of Lithuania, Livonia and Muscovy) by Maciej Strubicz from 1589; Lithuania by Gerard Mercator from 1595; and the so-called Radziwiłł's Map of the Grand Duchy of Lithuania from 1613.

Based on the analysis of the toponymic corpus of all these maps, Franczak proves that Pachołowiecki's printed map from 1580 did not have a direct effect on the later cartographic works. Such an influence was, however, exerted by its manuscript original, which shaped the image of the Lithuanian-Muscovite borderland in European cartography of the $17^{\text {th }}$ and $18^{\text {th }}$ centuries through the maps of Sulimowski and Strubicz.

Keywords: history of cartography, textology, textual criticism, Stanisław Pachołowiecki, Stanisław Sulimowski, Maciej Strubicz, Gerard Mercator, Polotsk, Principality of Polotsk, Grand Duchy of Lithuania, Belarus, toponymy, hydrography

Niniejsze opracowanie jest próbą pokazania, w jaki sposób narzędzia filologiczne, a w szczególności metoda krytyki tekstu, mogą znaleźć zastosowanie $\mathrm{w}$ analizie wczesnonowożytnych map, przyczyniając się do ustalenia zachodzących między nimi relacji. Inaczej mówiąc, celem tej pracy jest sprawdzenie, do jakiego stopnia wykorzystanie narzędzi, stosowanych od niemal dwustu lat w ustalaniu, jak przekazywane były teksty w średniowiecznych kodeksach, może być przydatne w określaniu, jak transmitowana była wiedza geograficzna na wczesnonowożytnych mapach. Pisząc o mapie, przyjmuję kulturoznawczą definicję J.B. Harleya, inną niż ta, którą zakłada tradycyjna 
historia kartografii, zajmująca się przede wszystkim dokumentowaniem i wartościowaniem mimetycznej relacji mapa-terytorium. Mapa jest w moim ujęciu traktowana jako tekstowo-ikoniczna redeskrypcja świata, funkcjonująca $\mathrm{w}$ ramach określonych praktyk kulturowych i w kontekście relacji władzy ${ }^{2}$. Na potrzeby niniejszego studium traktuję jednak tę definicję dosłowniej i „tekstualniej”: przedmiotem badań będzie toponimia, a więc szczególnego rodzaju językowy element mapy jako tekstu kultury - element poddający się procedurom krytyki tekstu wypracowanym przez nowożytną filologię. Taka konserwatywna $w$ istocie, $\mathrm{z}$ punktu widzenia filologa, propozycja metodologiczna ma szansę, być może, okazać się paradoksalną archaizującą innowacją w zakresie historii i krytyki kartografii.

Tak rozumianemu celowi nadrzędnemu będą towarzyszyły trzy cele szczegółowe. Po pierwsze, sporząazenie pełnego indeksu toponimów pojawiających się na mapie Descriptio Ducatus Polocensis (Opisanie Księstwa Połockiego) Stanisława Pachołowieckiego, wyrytowanej w Rzymie przez Giovanniego Battistę Cavalieriego w 1580 roku, oraz identyfikacja i opis tych toponimów ${ }^{3}$. Po drugie, pokaza-

2 J.B. Harley, The New Nature of Maps. Essays in the History of Cartography, ed. by P. Laxton, Baltimore 2001, s. 35-36: „Far from holding up a simple mirror of nature that is true or false, maps redescribe the world - like any other document - in terms of relations of power and of cultural practices, preferences and priorities. [...] Maps are text in the same senses that other nonverbal sign systems [...] are texts" [„Dalekie od bycia zwykłym zwierciadłem natury, prawdziwym lub fałszywym, mapy poddają świat redeskrypcji w kategoriach relacji władzy oraz praktyk kulturowych, preferencji i priorytetów. [...] Mapy są tekstami w tym samym znaczeniu, w jakim są nimi [...] inne niewerbalne systemy znakowe" - tłum. G.F.].

${ }^{3}$ Opis zabytku: K. Kozica, Charakterystyka prac kartograficznych Stanistawa Pachołowieckiego (1580), „Terminus” 19 (2017), z. 1 (42), s. 37-59; transkrypcja i przekład łacińskich inskrypcji: G. Franczak, Atlas Księstwa Połockiego Stanisława Pachołowieckiego z 1580 roku - transkrypcja i przekład, „Terminus” 19 (2017), z. 1 (42), s. 61-74. Rezygnuję tu również z omawiania literatury, jaką obrósł Atlas Połocki - jej pełny, krytyczny przegląd daje K. Łopatecki, Okoliczności powstania i przydatność wojskowa mapy Descriptio Ducatus Polocensis Stanisława Pachotowieckiego (1580), „Terminus” 19 (2017), z. 1 (42), s. 75-126, oraz idem, Ryciny prezentujące kampanię połocka 1579 roku jako jednolita kompozycja kartograficzna, 
nie, w jaki sposób następowało ich przejmowanie przez kartografię europejską XVI-XVIII wieku (m.in. włączenie nazw z mapy Księstwa Połockiego w obręb map Gerarda Merkatora) i zaproponowanie hipotetycznej genealogii toponimicznego obrazu Połocczyzny wywodzącego się z mapy Pachołowieckiego. Po trzecie wreszcie, próba pokazania poprzez nazewnictwo, w jaki sposób przebiegał proces kolportowania nowej wiedzy geograficznej, a zarazem kartograficznego przekazu propagandowego.

Na korpus map-tekstów, które czynię tu przedmiotem rozważań, składają się, prócz mapy Pachołowieckiego, cztery inne powiązane z nią zabytki kartograficzne. Chronologiczne pierwszeństwo ma zachowany w watykańskich papierach po legacie papieskim Antoniu Possevinie odrys mapy królewskiego dworzanina Stanisława Sulimowskiego, przedstawiający teatr działań wojennych w czasie wypraw połockiej i wielkołuckiej (1579-1580) ${ }^{4}$. Druga mapa to szeroko dyskutowana Magni Ducatus Lithuaniae, Livoniae et Moscoviae descriptio (Opisanie Wielkiego Księstwa Litewskiego, Inflant i Moskwy) Macieja Strubicza, opublikowana w kolońskim wydaniu Polonii Marcina Kromera w 1589 roku$^{5}$. Trzecia to mapa Litwy (Lithuania) Gerarda Merkatora, zamieszczona w pośmiertnym wydaniu jego atlasu w 1595 roku$^{6}$. Czwarta wreszcie jest szczytowym osiągnięciem kartografii polsko-litewskiej: to słynna Mapa Wielkiego Księstwa

„Terminus” 19 (2017), z. 1 (42), s. 157-191. Na potrzeby niniejszego studium korzystałem z egzemplarza Descriptio Ducatus Polocensis z Kolekcji dr. Tomasza Niewodniczańskiego, dep. Zamek Królewski w Warszawie - Muzeum, sygn. TN 2464.

${ }^{4}$ Unikatowa kopia rękopiśmiennej mapy Sulimowskiego: Archivio Segreto Vaticano, Segreteria di Stato, Polonia, sygn. 15A, k. 88. Jak ustalił Karol Łopatecki (K. Łopatecki, Okoliczności powstania i przydatność wojskowa mapy..., s. 81, 99-100), oryginał tej mapy operacyjnej powstał na potrzeby wojenne jeszcze przed kampanią wielkołucką, tj. przed lipcem 1580 roku.

${ }^{5}$ M. Strubicz, Magni Ducatus Lithuaniae, Livoniae et Moscoviae descriptio, Köln 1589. Korzystam z egz. z Kolekcji dr. Tomasza Niewodniczańskiego, dep. Zamek Królewski w Warszawie - Muzeum, sygn. TN 2456.

${ }^{6}$ G. Mercator, Lithuania, w: idem, Atlas sive Cosmographicae meditationes de fabrica mundi et fabricati figura, Duisburg 1595, tab. XXVII. Korzystam z egz. z Ko- 
Litewskiego Radziwiłłów (tzw. mapa Radziwiłłowska) opracowana przez zespół kartografów i rytowników (w tym Macieja Strubicza i Tomasza Makowskiego) na zlecenie Mikołaja Krzysztofa Radziwiłła „Sierotki”, znana z drugiego jej wydania z 1613 roku?.

Wagi Descriptio Ducatus Polocensis, będącej częścią bezprecedensowego w polsko-litewskiej kartografii zamysłu i przedsięwzięcia, które Jakub Niedźwiedź celnie nazywa Atlasem Księstwa Połockiego, nie sposób przecenićs. Znany i uznany od dawna jest jej fundamentalny, choć zapośredniczony przez prace Sulimowskiego i Strubicza, wkład w obraz Połocczyzny w kartografii europejskiej aż po wiek XVIII. Między innymi - i w sposób, jak sądzę, najtrwalszy - właśnie $\mathrm{w}$ aspekcie nazewnictwa. Pionierskie badania $\mathrm{w}$ tym zakresie są zasługą Karola Buczka, który już w 1933 roku wskazał na filiację pomiędzy połocką mapą Pachołowieckiego (jej zaginioną wersją rękopiśmienną raczej niż rzymskim drukiem G.B. Cavalieriego) a kopią mapy S. Sulimowskiego z Tajnego Archiwum Watykańskie-

lekcji dr. Tomasza Niewodniczańskiego, dep. Zamek Królewski w Warszawie - Muzeum, sygn. TN 1127.

7 Najstarsze zachowane, drugie, samodzielne wydanie tej mapy ściennej, opracowanej najpewniej przez Macieja Strubicza i naszkicowanej przez Tomasza Makowskiego, gotowej już w 1599 roku i opublikowanej po raz pierwszy przed 1607, ukazało się w roku 1613 jako Magni Ducatus Lithuaniae caeterarumque regionum illi adiacentium exacta descriptio, wyrytowane przez Hessela Gerritsza i odbite $\mathrm{z}$ czterech płyt miedziorytniczych $\mathrm{w}$ amsterdamskiej oficynie Willema Janszoona Blaeu’a (egz. w Herzogin Anna-Amalia Bibliothek w Weimarze, sygn. Kt 237-201 S). Korzystam z egzemplarza stanu drugiego mapy (1631 roku), identycznego z pierwszym pod względem obrazu Połocczyzny: Kolekcja dr. Tomasza Niewodniczańskiego, dep. Zamek Królewski w Warszawie - Muzeum, sygn. TN 1141. Najpełniejsze i najnowsze opracowania dotyczące mapy Radziwiłłowskiej: S. Alexandrowicz, Kartografia Wielkiego Księstwa Litewskiego od XV do połowy XVIII wieku, Warszawa 2012, s. 72-122; G. Schilder, Monumenta Cartographica Neerlandica, vol. 9: Hessel Gerritsz (1580/81-1632). Master Engraver and Map Maker, Who 'Ruled' the Seas, Houten 2013, s. 195-218.

${ }^{8}$ Zob. J. Niedźwiedź, Atlas Księstwa Połockiego Stanisława Pachołowieckiego (1580): propaganda, genologia i tworzenie wiedzy geograficznej, „Terminus” 19 (2017), z. 1 (42), s. 127-155. 
go9 . Buczek wysunął też jako pierwszy hipotezę o zależności między Pachołowieckim, choć za pośrednictwem niezachowanej mapy teatru wypraw batoriańskich Macieja Strubicza z około 1582 roku, a Lithuanią Gerarda Merkatora z 1595 roku, zwracając między innymi uwagę na cechującą ją polską pisownię nazw ${ }^{10}$. Nieco więcej uwagi nazewnictwu poświęcił kontynuator dzieła Buczka, Stanisław Alexandrowicz, analizując źródła mapy Radziwiłłowskiej (1613), której autorstwo konsekwentnie przypisywał Tomaszowi Makowskiemu, malarzowi i klientowi M.K. Radziwiłła „Sierotki”. Uczony wskazywał na zasadnicze odwzorowanie w „połockiej” partii mapy Radziwiłłowskiej, z pewnymi poprawkami, znanej z mapy Pachołowieckiego hydrografii, z niektórymi jej niedoskonałościami włącznie, by wspomnieć choćby „błędny kierunek biegu i zakręty, będące wytworem fantazji rysownika" rzek Obol i Połoty czy mylną lokalizację miejscowości Plisa ${ }^{11}$. W TABLICY synoptyczneJ (VI), zawierającej zestawienie niewielkiej tylko części toponimów pojawiających się aż na dziewięciu mapach (w tym Pachołowieckiego, Strubicza z 1589 roku oraz Lithuanii Merkatora i mapy Radziwiłłowskiej), znajdujemy osiem przykładowych nazw miejscowych spośród piętnastu wprowadzonych przez Pachołowieckiego, a których nie było na mapach jego poprzedników ${ }^{12}$. Do Descriptio Ducatus Polocensis wracał

9 Zob. K. Buczek, Dorobek kartograficzny wojen Stefana Batorego, „Wiadomości Służby Geograficznej” 8 (1934), z. 3, s. 5 i n.

10 Zob. idem, Kartografia polska w czasach Stefana Batorego, „Wiadomości Służby Geograficznej" 7 (1933), z. 2, s. 87 i n.

11 S. Alexandrowicz, Mapa Wielkiego Księstwa Litewskiego Tomasza Makowskiego z 1613 r. tzw. „radziwiłłowska”, jako źródło do dziejów Litwy i Białorusi, „Studia Źródłoznawcze” 10 (1965), s. 43.

12 Zob. ibidem, s. 63. Badacz ujmuje w zestawieniu następujące nazwy miejscowe z mapy Pachołowieckiego: Čašniki-Czaśniki, Dzisna, Hlybokaje-Głębokie, Jeziaryšča-Jezieryszcza, Ula-Ułła, Usviaty-Uświat, Viata-Wiata i Varoničy-Woroniecz. Tu i dalej, by ułatwić zlokalizowanie ich w indeksach i w części opisowej, toponimy z mapy Pachołowieckiego podaję w podwójnej wersji językowej - transkrybowanej ze współczesnej postaci białoruskiej oraz polskiej, wyjąwszy nazwy będące w obu wersjach homografami. 
Alexandrowicz w swoich kolejnych pracach. Omawiając ją obszernie w artykule z 1998 roku, pisał na temat toponimii:

Znacznie lepiej wypada nazewnictwo rzek i miejscowości. Identyfikacja ich okazała się możliwa we wszystkich wypadkach, choć bywała utrudniona przez późniejszy zanik niektórych i zmianę nazw innych osiedli [...]. Dodatkowym utrudnieniem są liczne zniekształcenia nazw, czasem już przez kartografa, częściej jednak przez sztycharza ${ }^{13}$.

Wreszcie - w trzecim uzupełnionym wydaniu monumentalnego studium o kartografii Wielkiego Księstwa Litewskiego stwierdzał, w odniesieniu do Lithuanii Merkatora:

Przedstawiając północne ziemie Wielkiego Księstwa, posłużył się Merkator mapą Księstwa Połockiego Stanisława Pachołowieckiego (1580), z której przejął 12 miejscowości nie występujących we wcześniejszym materiale kartograficznym. Mogły one zresztą dostać się na Lithvanię za pośrednictwem niezachowanej a rozszerzonej redakcji mapy Strubicza ${ }^{14}$.

Krótki ten przegląd daje wystarczające wyobrażenie o niemałym zamieszaniu panującym w trudnej do rozstrzygnięcia kwestii - bezpośredniej lub zapośredniczonej zależności późniejszych map od Descriptio Ducatus Polocensis. W świetle dotychczasowych ustaleń i na podstawie analizy porównawczej korpusu nazewniczego na mapie Pachołowieckiego i na mapach odeń zależnych, wypada uznać za trafne przypuszczenia Karola Buczka i sprostować niektóre pokutujące po dziś w historii kartografii błędne twierdzenia Alexandrowicza.

${ }^{13}$ S. Alexandrowicz, Źródła kartograficzne do wyprawy połockiej Stefana Batorego roku 1579, w: Od armii komputowej do narodowej (XVI-XX w.), red. Z. Karpus, W. Rezmer, Torun 1998, s. 27.

${ }^{14}$ S. Alexandrowicz, Kartografia Wielkiego Księstwa Litewskiego..., s. 66, przyp. 139. Wspomnianych dwanaście miejscowości to: Bieĺniaki-Bielniaki, Babyničy-Bobynicze, Budavičy-Budowicze (uczony, błędnie transkrybując nazwę z mapy Pachołowieckiego jako Badonieze, oznacza ją symbolem NN, notabene wbrew wcześniejszemu twierdzeniu o „identyfikacji we wszystkich wypadkach”), Halubičy-Hołubicze, Jeziaryšča-Jezieryszcze, Psuia-Psuja, Suša-Susza, Ula-Ułła, Usviaty-Uświat, Ušača-Uszacz, Viata-Wiata i Varoničy-Woroniecz. 
Zacznę od niezbędnych precyzacji natury metodologiczno-terminologicznej. Zgodnie $\mathrm{z}$ nadrzędnym celem niniejszej pracy, postuluję zastosowanie do badań nad dawnymi mapami, a konkretnie nad ich często niezwykle rozbudowanymi partiami tekstowymi, z toponimią włącznie, wypróbowanych procedur krytyki tekstu, pozwalających na sformułowanie, poprzez kolacjonowanie przekazów i na podstawie błędów znaczących (łączących i dzielących poszczególne gałęzie tradycji), hipotez filiacyjnych ${ }^{15}$. Tradycję rozumiem jako ze-

15 Brakuje solidnych i nowoczesnych polskojęzycznych opracowań z zakresu tekstologii, edytorstwa naukowego czy najbardziej nas tu interesujących procedur krytyki tekstu (metoda stemmatyczna czy metoda Lachmanna). Brak również przekładów kanonicznych opracowań niemieckich, angielskich lub włoskich - choćby Paula Maasa (P. Maas, Textkritik, 4 Aufl., Leipzig 1960; wyd. ang.: idem, Textual Criticism, Oxford 1958; kilkunastrostronicowy fragment w przekładzie polskim: idem, Krytyka tekstu. Fragmenty, przeł. K. Sybilska, „Pamiętnik Literacki”, 85 (1994), z. 2, s. 188-206), czy rewidujących metodę Lachmanna prac Giorgia Pasqualiego (G. Pasquali, Storia della tradizione e critica del testo, Firenze 1988) i Sebastiana Timpanaro (S. Timpanaro, La genesi del metodo del Lachmann, Torino 2004; wyd. ang.: idem, The Genesis of Lachmann's Method, ed. and transl. by G.W. Most, Chicago 2005). Nie wypełniają tej luki ani polskie podręczniki Górskiego (K. Górski, Tekstologia i edytorstwo dzieł literackich, Torun 2011) czy Lotha (R. Loth, Podstawowe pojęcia i problemy tekstologii i edytorstwa naukowego, Warszawa 2006), ani też niedawny przekład dyskusyjnego podręcznika Alfredo Stussiego (A. Stussi, Introduzione agli studi di filologia italiana, Bologna 2002; wyd. pol.: idem, Wprowadzenie do edytorstwa i tekstologii, przeł. M. i P. Salwa, Gdańsk 2011), przynoszący, jak wykazał Janusz Gruchała, szereg nieporozumień terminologicznych (zob. J. Gruchała, Tekstologia wyłożona „modo Italico” (O książce Alfredo Stussiego „Wprowadzenie do edytorstwa i tekstologii”), „Wielogłos. Pismo Wydziału Polonistyki UJ” 2012, nr 3 (13), s. 265-272). Refleksje i dyskusje doświadczonych wydawców tekstów staropolskich, między innymi J. Gruchały, R. Grześkowiaka, A. Karpińskiego i R. Krzywego, rozsiane są po czasopismach i wydawnictwach zbiorowych - nie miejsce tu, by je referować. Na użytek proponowanej tu analizy traktuję jako modelowe zastosowanie metody stemmatycznej przez Radosława Grześkowiaka, obejmujące opis źródeł, skolacjonowanie przekazów, ustalenie tradycji tekstu i zobrazowanie jej w postaci stemmy, wreszcie próbę restytucji tekstu na przykładzie poetyckiego cyklu Kaspra Twardowskiego: R. Grześkowiak, Komentarz edytorski, II. Uwagi do tekstu, w: K. Twardowski, Lekcyje Kupidynowe, wyd. R. Grześkowiak, Warszawa 1997 (Biblioteka Pisarzy Staropolskich, t. 7), s. 35-73. 
spół rękopiśmiennych i drukowanych przekazów (świadków), zawierających interesujący nas tekst i powiązanych w sieć zależności filiacyjnych, z następstwem kolejnych kopii źródłowego autografu. Ustalając te zależności, posługuję się pojęciem archetypu (przekazu źródłowego, z którego wywodzi się cała tradycja tekstu), a także antygrafu czy przodka - przekazu, z którego powstał dany odpis lub odpisy. Postępując zgodnie $\mathrm{z}$ unowocześnioną w XX wieku przez takich filologów jak Pasquali i Timpanaro metodą Lachmanna, dokonuję krytycznej oceny przekazów, by poddać je następnie kolacjonowaniu (collatio): porównuję lekcje (inaczej - warianty formalne) nazw własnych na mapie Pachołowieckiego i w przekazach od niej zależnych. W toku tej procedury określam charakter błędów, jakie powstają $\mathrm{w}$ trakcie kopiowania antygrafu. Jedna ich grupa to błędy łączące (tzw. Bindefehler), czyli takie, które w dwóch lub więcej przekazach nie mogły powstać niezależnie od siebie, wolno zatem przypuścić, że przekazy te pochodzą od wspólnego przodka. Druga grupa to błędy dzielące (Trennfehler): błędna lekcja cechująca przykładowy przekaz A wobec poprawnej lekcji w przekazie B pozwala wykluczyć pionową zależność B od A (kopista B nie byłby w stanie skorygować błędu antygrafu). Rezultatem jest obrazujące hipotetyczną transmisję tekstu drzewo genealogiczne, czyli stemma ${ }^{16}$.

Podejmując niniejszą próbę, mam świadomość cząstkowości tej procedury. Krytyka tekstu dawnej mapy winna współdecydować o kształcie obrazującej tradycję stemmy - nazwijmy ją roboczo stemma chartarum. Winna, lecz w koniecznym współdziałaniu z metodami analizy wypracowanymi przez historię kartografii, a obejmującymi geograficzną orientację mapy, jej przybliżoną skalę, siatkę zniekształceń, obecność na mapie różnego rodzaju obiektów (choćby sygnatur miejscowości) i relacje między nimi, obraz hydro-

${ }^{16}$ Mimo że termin „stemma” mógłby być potraktowany jako rzeczownik rodzaju nijakiego, będę posługiwał się nim w rodzaju żeńskim, zgodnie z modelową praktyką edytorską R. Grześkowiaka (zob. R. Grześkowiak, Komentarz edytorski, II. Uwagi do tekstu..., s. 44 i n.). 
grafii, wreszcie wszelkie składniki ikoniczne mapy - od schematycznych przedstawień ukształtowania terenu i zalesienia, poprzez niejednokrotnie bardzo rozbudowane sceny historyczne, batalistyczne czy obyczajowe, po elementy heraldyczne i emblematyczne ${ }^{17}$. Istotą wczesnonowożytnej mapy jest znacznie ściślejsze i bogatsze niż w dzisiejszej kartografii zespolenie obrazu i tekstu: najtrafniejszą $\mathrm{w}$ tej mierze wydaje się proponowana przez badaczy anglosaskich, na przykład Briana Harleya, definicja mapy jako „wyobrażenia z natury retorycznego” (,inherently rhetorical image”) ${ }^{18}$. Przeprowadzone analizy, zaznaczmy to raz jeszcze, dotyczą wyłącznie tradycji tekstu nazewniczego w obrębie przedstawienia Połoccczyzny i terenów bezpośrednio przyległych - tradycji wywodzącej się z mapy Pachołowieckiego, a przekazanej przez scharakteryzowane wyżej późniejsze mapy polskie i europejskie obejmujące ten obszar ${ }^{19}$. Pełne zestawienie nazw podajemy w TABLICY SYNOPTYCZNEJ (VI), zaś rezultatem analizy jest poniższa stemma:

17 Wczesnonowożytną mapę ujmuje jako „emblemat kartograficzny” J. Niedźwiedź, Atlas Księstwa Połockiego Stanisława Pachłowieckiego..., s. 139-146.

18 J.B. Harley, The New Nature of Maps..., s. 37.

19 Pełna stemma Lithuanii Merkatora czy mapy Radziwiłłowskiej byłaby znacznie bardziej skomplikowana, o ile w ogóle możliwa do nakreślenia. Niewielką wartość przedstawiają sobą bazujące na potraktowanych z dużym uproszczeniem twierdzeniach Alexandrowicza schematy filiacyjne, zaproponowane przez Jarosława Łuczyńskiego w najnowszym, niewiele niestety wnoszącym do stanu badań kompendium historii kartografii ziem polskich. W szczególności tyczy się to schematów odnośnie do Lithuanii Merkatora (J. Łuczyński, Ziemie polskie w kartografii drugiej połowy XVI wieku, w: S. Alexandrowicz, J. Łuczyński, R. Skrycki, Historia kartografii ziem polskich do XVIII wieku, Warszawa 2017, s. 108) czy „etapów rozwoju obrazu kartograficznego ziem Polski i Wielkiego Księstwa Litewskiego” w europejskiej kartografii XVI-XVII wieku (idem, Rzeczpospolita na mapach kartografów zachodnioeuropejskich z XVII i pierwszej połowy XVIII w., w: S. Alexandrowicz, J. Łuczyński, R. Skrycki, Historia kartografii.., s. 149). Wynika z nich między innymi, jakoby Merkator odwzorował obraz Połocczyzny z kolońskiej mapy Strubicza z 1589 roku (nb. pod nieistniejącym tytułem Teatr wojen batoriańskich) oraz z mapy Ducatus Polocensis Pachołowieckiego z 1579 roku (a zatem z niezachowanej wersji rękopiśmiennej). Obie te sugestie, nawet tylko w świetle analizy toponimii wymienionych map, są nie do obronienia. 


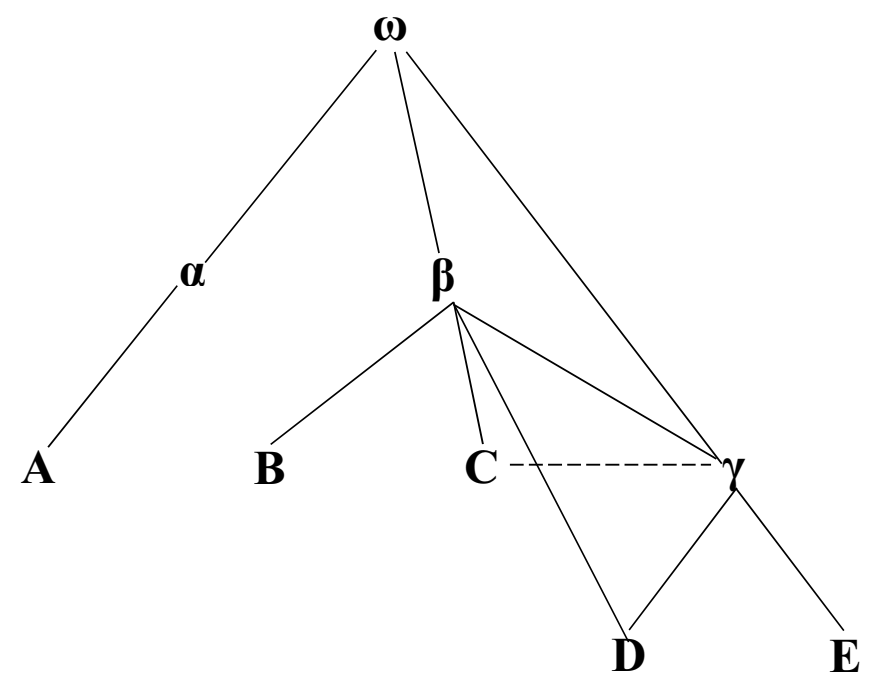

Legenda

$\boldsymbol{\omega}$ - Archetyp: oryginalna rękopiśmienna mapa Pachołowieckiego (1579)

$\boldsymbol{\alpha}$ - Kopia mapy Pachołowieckiego wykorzystana przez G.B. Cavalieriego

$\boldsymbol{\beta}$ - Niezachowana rękopiśmienna mapa S. Sulimowskiego

$\gamma$ - Niezachowana mapa M. Strubicza (po 1582)

A - S. Pachołowiecki, G.B. Cavalieri, Descriptio Ducatus Polocensis (1580)

B - Rękopiśmienna kopia mapy S. Sulimowskiego (1580)

C - M. Strubicz, Magni Ducatus Lithuaniae, Livoniae et Moscoviae descriptio (1581, druk 1589)

D - G. Merkator, Lithuania (1595)

E - T. Makowski, M. Strubicz, Magni Ducatus Lithuaniae ... exacta descriptio - mapa Radziwiłłowska (1613)

Wolno założyć, że pomiędzy oryginalnym szkicem Pachołowieckiego (archetyp $\omega)$ a opartymi na nim rękopiśmiennymi i druko-wanymi mapami (A-E) istniały niezachowane do dziś przekazy pośrednie. Symbolem a oznaczam niezachowany antygraf, jakim posłużył się Cavalieri, rytując Descriptio Ducatus Polocensis (A). 
Pisownia nazw na mapie Pachołowieckiego-Cavalieriego zdradza rękę rytownika niewładającego polskim i ruskim - łatwo w tej sytuacji o błędy w odczytaniu niezbyt zapewne starannych zapisów przodka. Świadczy o tym szereg lekcji, które można uznać za typowe błędy dzielące, na przykład Budowieze (Budavičy-Budowicze), Crafniki (Čašniki-Czaśniki), Holubiez (Halubičy-Hołubicze), Psina (Psuja), Vuoronec (Varoničy-Woroniecz), Vwiata (Wiata), Vuiesniczko (Viesnick-Wiestnick), czy zupełnie już włosko brzmiące Tawicelle (Zaviačellie-Zaweczele) ${ }^{20}$. Cechą charakterystyczną dla rzymskiego sztychu, odróżniającą go od pozostałych przekazów, jest też latynizacja, być może z myślą o zachodnim odbiorcy, niektórych toponimów - Braflauia (Braslaŭ-Brasław), Horodcú (Haradok-Horodek), Polockum (Polack-Połock), Socolum (Sokal-Sokół) czy Witebfcúm (Vicebsk-Witebsk). Roboczy wniosek z powyższych rozważań sformułowałbym następująco: rzymski druk Cavalieriego z 1580 roku nie wpłynął bezpośrednio na żadną z poźniejszych prac kartograficznych - służyć nam może natomiast jako najpełniejszy, choć zniekształcony przekaz archetypu (w), z którego wywodzi się równolegle tradycja zależna od prac Sulimowskiego $(\boldsymbol{\beta})$ i Strubicza $(\boldsymbol{\gamma})$.

20 Spostrzeżenia te uchylają wątpliwości co do autorstwa rzymskiego sztychu, wymienionych tu błędów nie mógłby bowiem, jak sądzę, popełnić Tomasz Treter, któremu Alexandrowicz przypisuje jego wyrytowanie (zob. S. Alexandrowicz, Kartografia Wielkiego Księstwa Litewskiego..., s. 96: „wysztychowana w Rzymie u Jana [!] Cavalieriego, zapewne przez Tomasza Tretera"; zob. też ibidem, s. 172, przyp. 367). Analogiczną pewność miałbym również w przypadku planu Obsidio et expugnatio munitiss[imae] arcis Polocensis (Oblężenie i zdobycie warownej twierdzy połockiej), wbrew opinii Alexandrowicza, jakoby był on „sporządzony przez Stanisława Pachołowieckiego, a wyrytowany [...] w warsztacie Jana Baptysty Cavalieriego (z pewnością przez Tomasza Tretera)" (ibidem, s. 173; S. Alexandrowicz, J. Łuczyński, R. Skrycki, Historia kartografii ziem polskich..., s. 269). Pod względem stylistycznym miedzioryt ten nie odbiega ani od Opisania Księstwa Połockiego, ani od innych analogicznych prac wyszłych spod prasy Cavalieriego, by wspomnieć choćby plan oblężenia Dieppe (Descritione della terra et castello di Dieppa assediata..., 1589). Zob. G. Franczak, Rzymski łącznik: Giovanni Battista Cavalieri (1525-1601), rytownik Hozjusza i Tretera (w przygotowaniu). 
Mapa Pachołowieckiego-Cavalieriego zawiera ogółem osiemdziesiąt pięć toponimów - sześćdziesiąt siedem nazw miejscowości oraz osiemnaście rzek i jezior. Spośród map wywodzących się ze wspólnego archetypu najwięcej nazw wspólnych - aż sześćdziesiąt dwie - pojawia się na watykańskiej kopii pozbawionej tytułu mapy operacyjnej kampanii połockiej i wielkołuckiej Stanisława Sulimowskiego (świadek B, zob. il. 1). Analiza tego zespołu nazewniczego potwierdza dawne przypuszenia Karola Buczka, który pisał:

Batory nie dał oczywiście oryginału pracy Sulimowskiego, lecz jej kopię, a nie wiadomo również, czy nasz jezuita [Antonio Possevino - G.F.] tę właśnie kopię przesłał do Rzymu. Raczej przypuścić należy, że tak nie było, niestaranne bowiem wykonanie kopii watykańskiej oraz liczne przekręcenia i opuszczenia w nazwach miejscowości wskazują, że nie pochodzi ona z pierwszej ręki ${ }^{21}$.

$\mathrm{Na}$ to, że watykańska mapa (B) pochodzi od innego przodka (oznaczam go symbolem $\boldsymbol{\beta}$ ) niż ten, z którego kopiował Cavalieri, wskazuje szereg danych. Po pierwsze, północno-zachodni i północny obszar Połocczyzny w dorzeczu Drysy (wzdłuż szlaków wiodących z Połocka w stronę Wielkich Łuk i Pskowa) jest tu znacznie bogatszy w nazwy ${ }^{22}$. Po drugie, brakuje na niej dwudziestu trzech nazw pojawiających się na sztychu Cavalieriego. Jedno z takich opuszczeń, obejmujące wsie Zaborje-Zaborze, Čarnievičy-Czerniejewicze i JaznaJazno na drodze przemarszu z Głębokiego przez Plisę do Dzisny, przekonująco tłumaczy Karol Łopatecki: zdaniem białostockiego historyka informacje te, przeniesione na mapę z itinerarium planowanego marszu latem 1579 roku na Połock, były w 1581 roku niepo-

21 K. Buczek, Dorobek kartograficzny..., s. 5.

22 Nazewnictwo mapy Sulimowskiego zasługiwałoby na osobne i całościowe opracowanie. Dla przykładu wystarczy wymienić oznaczone przez Sulimowskiego, a nieobecne u Pachołowieckiego-Cavalieriego miejscowości Oświeja (oswia) i Lisno (Lisno, pojawiające się odtąd na mapach Strubicza, Merkatora, wreszcie na mapie Radziwiłłowskiej i pochodnych) oraz jeziora Nieczerico (Niecierw), Głyboczno (Hlubokie), Wiatiterwo (wietritrowo) i Orono (Noron) między miastami Dryssą a Siebieżem. 


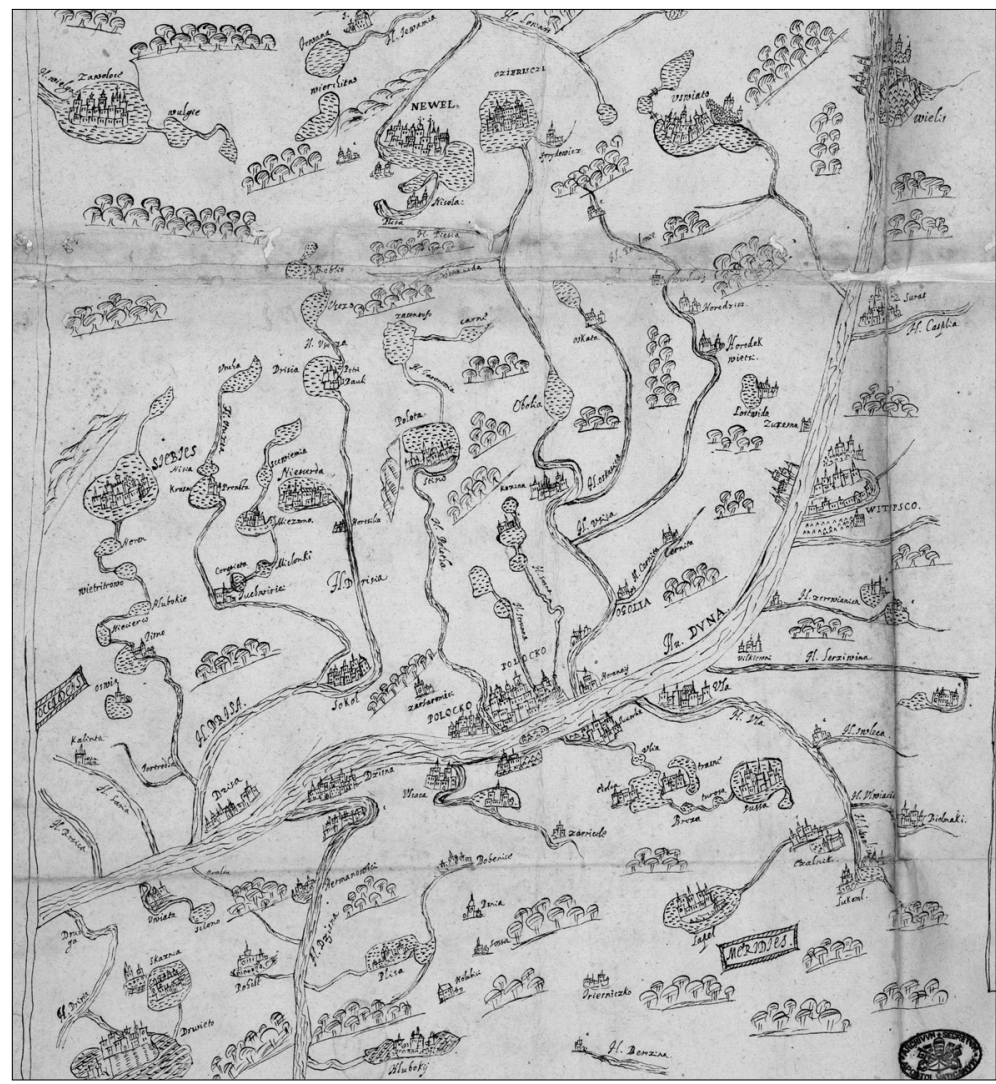

Il. 1. S. Sulimowski, rękopiśmienna mapa operacyjna kampanii połockiej i wielkołuckiej (Archivio Segreto Vaticano, Segreteria di Stato, Polonia, sygn. 15A, k. 88, za uprzejmą zgodą Archivio Segreto Vaticano) - fragment pokrywający się z mapą S. Pachołowieckiego

trzebne dowództwu armii polsko-litewskiej z punktu widzenia strategii, nie trzeba ich więc było umieszczać na nowej mapie ${ }^{23}$. Po trzecie,

23 Zob. K. Łopatecki, Okoliczności powstania i przydatność wojskowa mapy..., s. $98-100$. 
kilkanaście toponimów ma formę zniekształconą w wyniku błędnej lektury antygrafu. Są to typowe i nader częste błędy, pojawiające się w toku kopiowania tekstów rękopiśmiennych, na przykład odczytanie minuskułowego "c" jako „" (Cernita = Čarnica-Czernica), „u” jako „n” (Psnia = Psuia-Psuja), „k” jako „t” (trasne = Krasna-Krasne), czy majuskułowego „I” jako „S” (Skaznia = Ikazń). Są wreszcie toponimy, które na mapie Sulimowskiego mają postać poprawniejszą w porównaniu z rzymskim wydaniem Pachołowieckiego (np. Wiesniczko contra błędne Vuiesniczko), lub też podane w formie ruskiej zamiast polskiej (np. Hluboky contra Glebokie).

Znacznie bardziej skomplikowana jest kwestia filiacji jednej z najważniejszych polsko-litewskich map tego okresu - mapy Litwy, Inflant i Moskwy Macieja Strubicza z 1589 roku (świadek C) ${ }^{24}$. Kwestia ta zasługuje na nowe, pogłębione badania, choćby dlatego, że jest to jedyne zachowane dzieło sygnowane przez najwybitniejszego polskiego kartografa końca XVI wieku. Karol Buczek już w 1933 roku wysunął przypuszczenie, że mapa ta, jeśli idzie o przedstawienie Połocczyzny, zależna jest od prac kartografów pracujących a conto wypraw batoriańskich, uznał ją też za drugą, ulepszoną wersję mapy, jaką Strubicz przygotował jeszcze przed wyprawą połocką. Buczek datował tę mapę na koniec 1579 - początek 1580 roku, ale wkrótce, wobec odkrycia watykańskiej kopii mapy Sulimowskiego, przesunął swoje datowanie na rok $1581^{25}$.

Zidentyfikowano dwadzieścia siedem toponimów wspólnych dla Magni Ducatus Lithuaniae Strubicza (C) i rzymskiego sztychu Cavalieriego (A). Skolacjonowanie ich zdecydowanie wyklucza sugerowaną przez Alexandrowicza możliwość, by Strubicz wzorował się

24 Zob. K. Buczek, Kartografia polska w czasach Stefana Batorego, s. 85 i n.; idem, Dzieje kartografii polskiej od XV do XVIII wieku. Zarys analityczno-syntetyczny, Wrocław 1963, s. 42-43; S. Alexandrowicz, Kartografia Wielkiego Księstwa Litewskiego..., s. 62-64.

25 Zob. K. Buczek, Kartografia polska w czasach Stefana Batorego, s. 86; idem, Dorobek kartograficzny..., s. 7; idem, Dzieje kartografii polskiej..., s. 42-43. 
na Cavalierim ${ }^{26}$. Świadczą o tym takie lekcje, jak Hluboki (Hlybokaje-Głębokie), łączące mapę Strubicza z kopią mapy Sulimowskiego (świadek B: Hluboky), nie zaś z podającym polską formę Glebokie Pachołowieckim-Cavalierim. Uznaję zatem mapę Strubicza, zgodnie $\mathrm{z}$ tezą Buczka, za odrys z niezachowanej mapy Sulimowskiego (przodek $\boldsymbol{\beta}$ ), nie traktując jednak tej filiacji jako rozstrzygającej. Istnieje bowiem możliwość, że kolońska mapa Litwy i Inflant, jeśli weźmiemy pod uwagę dorzecze Dźwiny, nie jest, jak sądził Buczek, drukowaną wersją rękopiśmiennej pracy Strubicza z 1581 roku, starszej i uboższej w nazewnictwo niż niezachowana mapa teatru wojen moskiewskich z 1582 (przodek $\gamma$ ). Moglibyśmy mieć mianowicie do czynienia z redukcją tej ostatniej do formatu „przeglądówki” na potrzeby Polonii Kromera: zmodyfikować należałoby wówczas proponowaną tu stemmę, umieszczając Strubiczową Magni Ducatus Lithuaniae [...] descriptio obok dwóch innych odpisów przodka $\boldsymbol{\delta}$ - Lithuanii Merkatora i mapy Radziwiłłowskiej (E).

Istnienie mapy, którą oznaczam symbolem $\gamma$, przekonująco uzasadnił Buczek ${ }^{27}$. Była to, zgodnie z argumentacją opartą na drobiazgowej analizie treści mapy Litwy Merkatora, udoskonalona i uszczegółowiona wersja wcześniejszych map Litwy i Inflant Strubicza, powstała po zakończeniu wojny z Moskwą w 1582 roku na bazie niezachowanych materiałów: rękopiśmiennej mapy Sulimowskiego (przodek $\boldsymbol{\beta}$ ), z uzupełnieniami z rękopiśmiennej wersji Pachołowieckiego (archetyp w lub, co bardziej prawdopodobne, jego odpis) oraz, przypuszczalnie, $\mathrm{z}$ innych nieznanych nam map operacyjnych i itinerariów $\mathrm{z}$ wyprawy pskowskiej ${ }^{28}$. Uczony stwierdzał:

26 Por. S. Alexandrowicz, Kartografia Wielkiego Księstwa Litewskiego..., s. 64.

27 Zob. idem, Kartografia polska w czasach Stefana Batorego, s. 87-91. Zob. też: idem, Kartografia Wielkiego Księstwa Litewskiego..., s. 61-64.

28 Szerzej o mapach operacyjnych i itinerariach: K. Łopatecki, Mapy w planowaniu działań operacyjnych armii polskiej i litewskiej do początków panowania Stefana Batorego, „Terminus” 19 (2017), z. 3 (44), s. 567-607. 


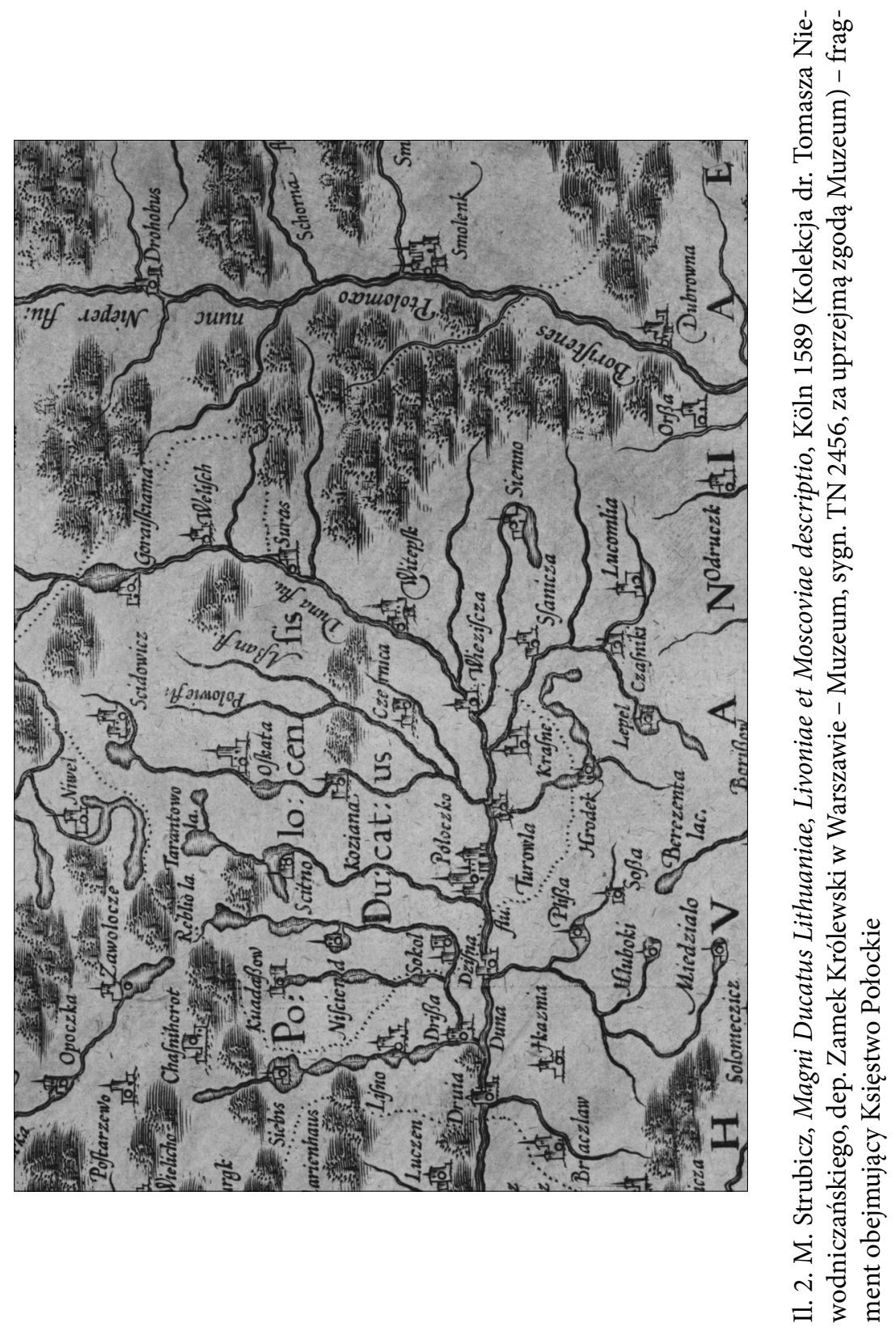


Podczas [...] gdy na wcześniejszej redakcji mapy teatru wojny było w granicach Wielkiego Księstwa tylko 99 miejscowości, to na późniejszej jest ich tu już 190, z czego tylko 37 spotykamy również na mapach z przed $1576 \mathrm{r}$. Radykalnie także zmienił Strubicz rysunek sieci wodnej. W dorzeczu Dźwiny uderza przede wszystkiem zmiana górnego biegu rzeki głównej na pd.-zach., podczas gdy na dawniejszej redakcji i u Pachołowieckiego płynęła ona w tej części ku pd. Pomnożona i przerobiona, w porównaniu do tych map, sieć wodna w zadźwińskiej części ziemi połockiej zdaje się wskazywać również na istnienie innych, prócz mapy Pachołowieckiego, materiałów kartograficznych dla tego obszaru ${ }^{29}$.

Jeśli przyjrzeć się bliżej korpusowi nazewniczemu obszaru Połocczyzny i krain przyległych na kolońskiej mapie Strubicza (świadek C; il. 2) i Lithuanii Merkatora z 1595 roku (świadek D; il. 3), przypuszczenia Buczka okazują się trafne. Po pierwsze, wszystkich dwadzieścia siedem nazw wspólnych dla drukowanej mapy Strubicza (C) i sztychu Pachołowieckiego-Cavalieriego (A) pojawia się również na mapie Merkatora (D). Tylko trzy z nich - Druia, Lepel i Turowla - mają identyczny zapis. Osiem inskrypcji ma taką samą postać na mapach Merkatora i Strubicza, różnią się jednak one od zapisów na mapie Pachołowieckiego $^{30}$. Kolejnych dziewięć to u Strubicza i Merkatora formy różniące się jedynie grafią ${ }^{31}$. Trzy dalsze odsyłają do wspólnego przodka $^{32}$. Najciekawsze - a zarazem decydujące - są cztery nazwy u Merkatora stanowiące typowe błędy dzielące wobec form na mapie Strubicza: Bracziaw, Hiuboki, Fkaznia i Wifcifcza zamiast poprawnych Braczlaw, Hluboki, Ikaznia oraz Wiezifcza. Nie znaczy to bynajmniej, że Merkator - a taki pogląd pokutuje w nowszej literaturze tematu - korzystał z kolońskiej mapy Strubicza, uzupełniając ją danymi

29 K. Buczek, Kartografia polska w czasach Stefana Batorego, s. 89. Na temat Lithuanii Merkatora zob. idem, Dzieje kartografii polskiej..., s. 43-45 i S. Alexandrowicz, Kartografia Wielkiego Księstwa Litewskiego..., s. 64-66.

30 Są to toponimy: Czafniki, Czernica, Koziana, Poloczko, Siebis, Sokol, Soßa i Witep $\int$.

31 Czernica, Drißa, Duna, Dzifna, Krafne, Lucomlia, Ofkata, Plißa i Suras.

32 Są to nazwy, w kolejności Strubicz (C)-Merkator (D): Nifcierd-Nifcierda, Scitno-Schitno, Scidowicz-Swidowicz. 


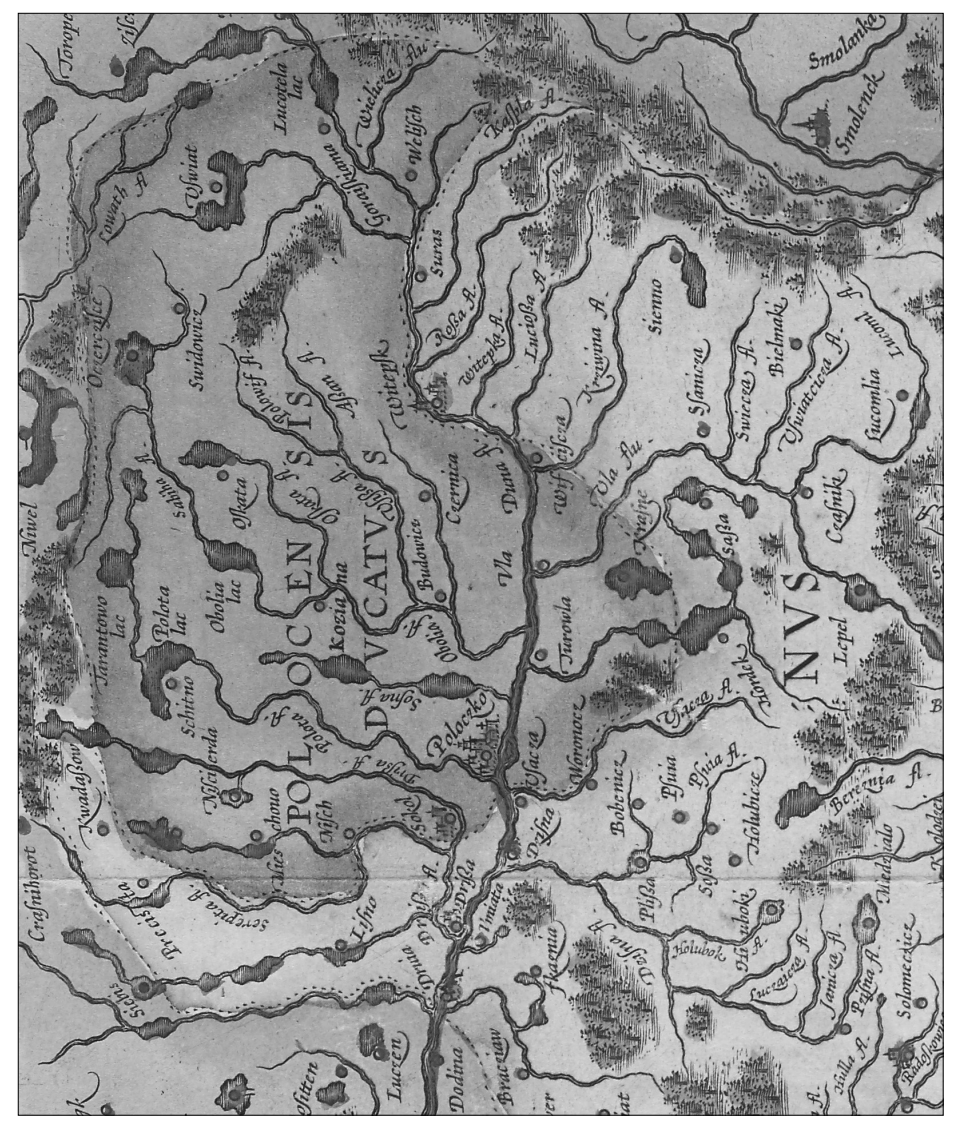

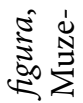

章

站

咅

इ $\frac{7}{5}$

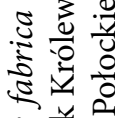

늘

\&

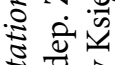

离

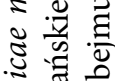

ำ

든

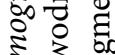

है

乙

: त्र

क ह

离

ई

离

उ $\frac{\pi}{0}$

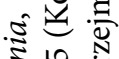

竎 约

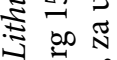

ศ

䒕高 元

常

ن

تं 
z rzymskiego sztychu Pachołowieckiego-Cavalieriego ${ }^{33}$. Oznacza to tyle, że kolońska mapa Strubicza, choć uboższa w nazwy, podaje je za swoim antygrafem zasadniczo w czystszej i poprawniejszej pisowni: błędy i warianty na mapie Merkatora mogły zresztą powstać w jego warsztacie lub pojawić się wcześniej, już na przesłanej mu kopii przodka $\boldsymbol{\delta}$. Do scharakteryzowanej tu grupy nazw trzeba dorzucić dwadzieścia pięć niepojawiających się na mapie Strubicza, a wspólnych dla Lithuanii Merkatora i Descriptio Ducatus Polocensis Pachołowieckiego. Skupię się na trzech przykładach, dowodzących niezbicie, że Merkator nie mógł posłużyć się rzymskim sztychem Cavalieriego.

Pierwszym przykładem jest pisownia toponimu Psuja. Spośród omawianych tu map jedynie Merkator i autorzy mapy Radziwiłłowskiej podają pisownię prawidłową - Pfuia, kontrastującą z błędnym odczytaniem grafemu "ui” na mapach Pachołowieckiego (Psina) i Sulimowskiego (Psnia). Nieznający polskiego czy ruskiego kartograf-kopista, a takim był Gerard Merkator, nie byłby w stanie samodzielnie emendować takich błędnych lekcji nazewniczych. Podobnie, przykład drugi, nie mógłby sprostować przeniesienia hydronimu z jednego cieku wodnego na inny. Myślę tu o nazwie Surazicza, którą Pachołowiecki oznacza wpadającą do Dźwiny w Surażu rzekę Kasplę: jako Kafpla pojawia się ona na mapie Merkatora, a wcześniej, w wariancie Casplia, na mapie Sulimowskiego. Trzeci przykład dotyczy zamieszania topograficzno-nazewniczego wokół lewych dopływów Dźwiny w okolicach Witebska - Wićby i Łuczesy. Otóż Merkator oznacza nazwą Wićby (Witepka fl., u Pachołowieckiego wiczba flu.) Łuczesę, którą z kolei Pachołowiecki podpisuje Ruczai

33 J. Łuczyński, Ziemie polskie w kartografii.., s. 107: „Dorzecze Dźwiny zaczerpnięto [w Lithuanii Merkatora - G.F.] z mapy Strubicza [tj. kolońskiej z 1589 roku - G.F.] z uzupełnieniami z mapy Stanisława Pachołowieckiego z 1579 roku (np. rzeki Widźba, Uła i inne). [...] Wykorzystał też [Merkator - G.F.] najnowsze mapy partykularne z terenu Litwy: teatru wojen z Moskwą M. Strubicza (najprawdopodobniej w nowszej, uzupełnionej wersji) i Księstwa Połockiego S. Pachołowieckiego z 1579 roku". W rezultacie na schematach filiacyjnych (ibidem, s. 108-109) mapa Strubicza z 1589 roku jawi się jako bezpośrednie źródło Merkatora. 
flu. Hydronim Roßa fl. opisuje u Merkatora Wićbę, zaś Lucioßa fl. (nazwa nieobecna u Pachołowieckiego) zostaje przesunięta jeszcze bardziej na południe.

Można więc uznać, że zmapowana i usiana przez Pachołowieckiego nienotowanymi wcześniej nazwami Połocczyzna zagościła na kartach europejskich atlasów dzięki pracom Strubicza. Mapa Litwy wydawana była w atlasach Merkatora i Hondiusa od roku 1595 po rok 1636, reprodukując za Strubiczem toponimię, hydrografię, granice, a także ekshumowaną przez obie strony konfliktu w Inflantach, $\mathrm{w}$ doraźnych celach politycznych i propagandowych, nazwę Polocensis Ducatus - w akwarelowanych wersjach mapy Księstwo Połockie najczęściej wyodrębniano $\mathrm{z}$ terytorium Wielkiego Księstwa Litewskiego inną barwą ${ }^{34}$. Najbardziej wpływową kartograficzną reprezentacją terytorium Litwy stała się jednak na cały wiek XVII i XVIII inna mapa - Radziwiłłowska Mapa Wielkiego Księstwa Litewskiego (świadek D) z 1613 roku. Toponimią tego pierwszorzędnego zabytku zajął się Michaił Spiridonaŭ w swych dwóch znakomitych pracach, będących do pewnego stopnia inspiracją dla proponowanej niżej partii indeksowo-opisowej. Białoruski historyk nie uwzględnił jednak w swoich badaniach źródłowej, choć zapośredniczonej roli mapy Pachołowieckiego ${ }^{35}$. W polskiej literaturze tematu natomiast

34 Językowymi strategiami konstruowania komunikatu propagandowego na mapie Pachołowieckiego zajmuję się w artykule: G. Franczak, Polotia recepta. Mapa Księstwa Połockiego jako tekst propagandowy (w przygotowaniu).

35 Zob. М. Спірыдонаў, Беларусь на карие Вялікага Княства Літоўскага 1613 2., „Гістарычны Альманах” 8 (2003), s. 3-55. W opisowym alfabetycznym indeksie nazw, z wyłączeniem hydronimów, uczony uwzględnia niestety wyłącznie miejscowości znajdujące się w granicach dzisiejszej Białorusi (zob. ibidem, s. 13-33: Дадатак 2 - Спіс населеных пунктаў Беларусі, што абазначаны на карце ВКЛ 1613 г., з дадатковымі гістарычнымі данымі). Mamy tu trzydzieści toponimów pokrywających się z mapą Pachołowieckiego. Są to (w nawiasie numer porządkowy indeksu Spiridonaŭa): Babyničy-Bobynicze (19), Braslaŭ-Brasław (33), CiotčaCiotcza (320), Čašniki-Czaśniki (330), Druja (110), Dzisna (100), Haradok-Horodek (78), Hlybokaje-Głębokie (85), Ikazń (136), Jeziaryšča-Jezieryszcze (118), Kamień (146), Kaziany-Koziany (143), Lukomĺ-Łukoml (186), Nieščarda-Nie- 
o rzekomej bezpośredniej zależności mapy Radziwiłłowskiej w zakresie przedstawienia Połocczyzny od Descriptio Ducatus Polocensis Pachołowieckiego pisał Alexandrowicz:

Zupełnie inaczej potraktowana została mapa księstwa połockiego, sporządzona przez Pachołowieckiego. Dzięki dużej skali (około 1 : 700 000), a co za tym idzie bogactwu szczegółów, mogła ona stanowić podstawę dla odpowiedniej partii mapy Makowskiego. Że taką rolę odegrała, wskazuje porównanie występujących na obszarze województwa połockiego i w jego sąsiedztwie miejscowości i sieci wodnej. Spośród 40 miejscowości na tej partii mapy Makowskiego, 33 były już oznaczone u Pachołowieckiego, a tylko siedem wprowadził Makowski. Jednak pracę Pachołowieckiego wykorzystał on krytycznie. Uległy poprawieniu nazwy, bardzo często zniekształcone przez sztycharza mapy Pachołowieckiego. [...] Zasługuje na uwagę, że oznaczone na mapie Makowskiego położenie topograficzne twierdz Koziana, Sitna, Sokoła, Suszy i Turowli z grubsza odpowiada szczegółom ich sytuacji na rysunkach (planikach) dołączonych do mapy Pachołowieckiego. Wskazuje to na sumienność, z jaką Makowski wykorzystywał dostępne materiały kartograficzne i ikonograficzne ${ }^{36}$.

Wolno oczywiście założyć, że autorzy mapy Radziwiłłowskiej mieli do dyspozycji również sztych Pachołowieckiego-Cavalieriego. Analiza toponimii wskazuje jednak, że poprawiając nazewniczy obraz Połocczyzny, posługiwali się oni raczej rękopiśmiennymi materiałami Sulimowskiego (przodek $\boldsymbol{\beta}$ lub jego odpis) oraz - rzecz

szczerda (224), Pahost-Pohost (227), Plisa (247), Polack-Połock (250), Psuja (255), Sianno-Sienno (304), Sitna-Sitno (202), Sokal-Sokół (285), Stary Liepieĺ-Lepel (295), Suraž-Suraż (300), Suša-Susza (302), Turoŭlia-Turowla (308), Ula-Ułła (61), Varoničy-Woroniecz (43), Vicebsk-Witebsk (52), Vierchniadzvinsk-Dryssa (47) i Voskata-Oskato (58). Autor podaje przy każdej miejscowości datę najstarszej wzmianki i krótki wykaz źródeł historycznych. Dodatkowym materiałem jest tabela nazw podająca toponim transkrybowany z mapy i jego współczesne odpowiedniki białoruski i rosyjski (brak odpowiedników polskich. Zob. ibidem, s. 34-42: Дадатак 3 - Спаланізаваныя назвы населеных пунктау Беларусі, што абазначаны на карие ВКЛ 1613 г.).

36 S. Alexandrowicz, Mapa Wielkiego Księstwa Litewskiego Tomasza Makowskiego..., s. 43. Ustalenia te powtórzył uczony słowo w słowo niemal pół wieku później: idem, Kartografia Wielkiego Księstwa Litewskiego..., s. 96-97. 
naturalna, zważywszy jego udział $\mathrm{w}$ redagowaniu dzieła - mapą Strubicza z 1582 roku (przodek $\gamma$ ). Spośród czterdziestu pięciu nazw wspólnych dla mapy Pachołowieckiego-Cavalieriego i Radziwiłłowskiej tylko cztery nie figurują na watykańskiej kopii Sulimowskiego ${ }^{37}$. Równie znaczące wydaje się porównanie $\mathrm{z}$ toponimią kolońskiej mapy Strubicza z 1589 roku (świadek C). Na mapie Radziwiłłowskiej brak zaledwie sześciu nazw: osady Czernica nad noszącym tę samą nazwę prawym dopływem rzeki Budowieść, zamku Krasne (!), Siebieża, oraz mniejszych miejscowości Szo (u Strubicza Soßa), Swirydowicze (Scidowicz; Swidowicz u Merkatora) i Wiażyszcze (Wiezifcza). Z kolei dwadzieścia cztery nazwy nieobecne na drukowanej mapie Strubicza (C) potwierdzone są bez wyjątku przez drugi przekaz wywodzący się od antygrafu $\boldsymbol{\beta}$ (świadek B - watykańska mapa Sulimowskiego $)^{38}$, mapę Merkatora $(\mathbf{D})^{39}$, lub wreszcie - aż szesnaście - przez obydwa te źródła ${ }^{40}$. Zaproponowana tu filiacja wydaje się w świetle tych faktów najbardziej prawdopodobna.

37 Są to miejscowości Sienno i Woroniecz (nb. na mapie Radziwiłłowskiej w błędnej postaci Woromecz) oraz rzeki Obol (Obola fl.) i Łuczesa (Luczofa fl.).

38 Są to trzy toponimy: Ciotča-Ciotcza (u Sulimowskiego Ciotca), HaradokHorodek (Horodek wietsi [= więtszy]) oraz Pahost-Pohost (Pohist).

39 Pięć toponimów: Budavičy-Budowicze (Budowice u Merkatora - hydro$\operatorname{nim}$ Budowiejz $f l$. na mapie Radziwiłłowskiej), rz. Lučosa-Łuczesa (Lucioßa $f l$. Luczofa fl.), rz. Obaĺ-Obol (Obolia fl. - Obola fl.), Varoničy-Woroniecz (Woronoczbłędne Woromecz) i rz. Vićba-Wićba (Witepka fl. - Widzba fl.).

40 Są to nazwy (lekcje w kolejności: Sulimowski-Merkator-mapa Radziwiłłowska): Babyničy-Bobynicze (Bobenice-Bobenicz-Bohomecz[!]), rz. Biarezina-Berezyna (fl. Berezina-Bereznia fl.[!]-Berezina fl.), rz. Čarniaŭka-Czerniawka ( $f l$. oskacica-Ojkata fl.-Ofkatczyca fl.), rz. Drysa (fl. Drisia i FL. DRISA-Drißa fl.-Driffa fl.), rz. Dzisna (fl. Dzisna-Dzifna fl.-Dziefna fl.[!]), Jeziaryšča-Jezieryszcze (OZIERISCZI-Oczerczifce[!]-Ozierzyßcia), rz. Kasplia-Kaspla (fl. Casplia-Kajpla fl.Cafpla $f l$.), rz. Krywinka-Krywina (fl. krziwina-Krziwina fl.-Krzywina fl.), jez. Obaĺ-Obol (Obolia-Obolia lac.-Obola lac.), rz. Palata-Połota (fl. Polotha-Polota fl.-Polota fl.), Psuja (Psnia[!]-Pfuia-Pfuia), zamek Suša-Susza (Sussa-Saßa[!]Sußa), Ula-Ułła (Ula-Vla-Vla), rzeka i miasto Ušača-Uszacz (Ufsaca-UfaczaVfzacza fl.), Usviaty-Uświat (uswiath-Ufwiat-Vswiach[!]) oraz rz. Uśviača-Uświata (fl. Vfwiacica-Ufwiatcicza fl.-Viwiatczyca[!]). 

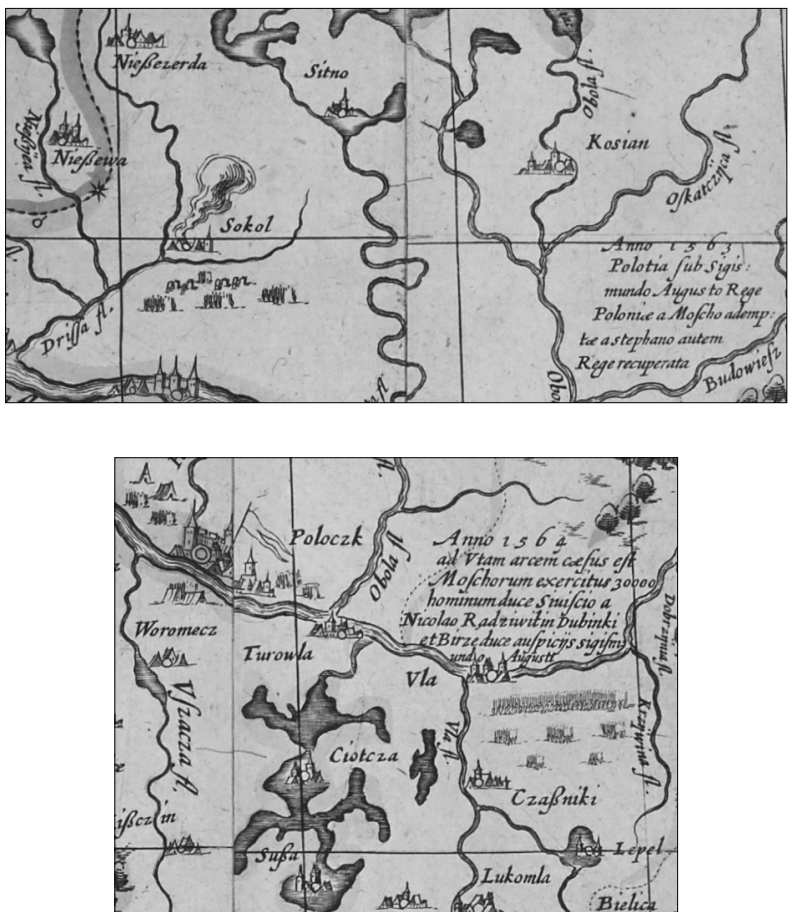

Il. 4-5. M. Strubicz, T. Makowski, Magni Ducatus Lithuaniae caeterarumque regionum illi adiacentium exacta descriptio, Amsterdam 1613 [1631] (Kolekcja dr. Tomasza Niewodniczańskiego, dep. Zamek Królewski w Warszawie - Muzeum, sygn. TN 1141, za uprzejmą zgodą Muzeum) - fragmenty

$\mathrm{Na}$ podstawie przeprowadzonych analiz można stwierdzić, że mapa Pachołowieckiego nie miała bezpośredniego wpływu na mapę Merkatora, choć miała wpływ na Sulimowskiego i Strubicza, z prac których korzystał Merkator. Przede wszystkim jednak oddziałała na mapę Radziwiłłowską a przez nią na obraz Połocczyzny i północnego pogranicza litewsko-rosyjskiego w kartografii europejskiej XVII i XVIII wieku. Na długo po zdobyciu i spaleniu w latach 1579-1580 twierdz Iwana IV Groźnego na ziemi połockiej - Kozian, Krasnego, Nieszczerdy, Sitna, Sokoła, Suszy i Turowli - ich nazwy, niektóre 

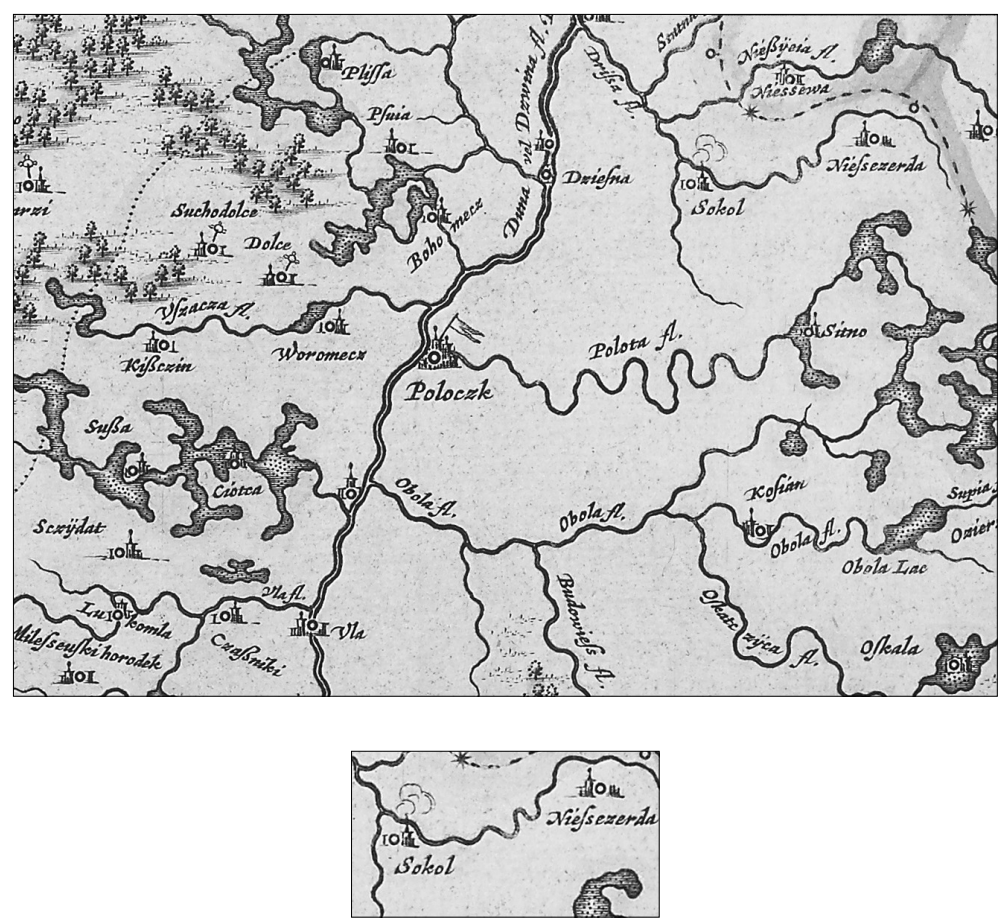

Il. 6-7. J. Blaeu, Magni Ducatus Lithuaniae et regionum adiacentium exacta descriptio, Amsterdam 1648 (Kolekcja dr. Tomasza Niewodniczańskiego, dep. Zamek Królewski w Warszawie - Muzeum, sygn. TN 1130, za uprzejmą zgodą Muzeum) - fragmenty

opatrzone na mapie historycznymi notatkami (zob. il. 4 i 5), gościły jeszcze, począwszy od przeróbki z 1648 roku, w atlasach Joana Blaeu’a (zob. il. 6 i 7) ${ }^{41}$, a w XVIII stuleciu, dzięki mapie Jana Nie-

41 J. Blaeu, Magni Ducatus Lithuaniae et regionum adiacentium exacta descriptio (1648). Korzystam z egz. z Kolekcji dr. Tomasza Niewodniczańskiego, dep. Zamek Królewski w Warszawie - Muzeum, sygn. TN 1130. 
przeckiego z 1749 roku, w atlasach spadkobierców J.B. Homanna ${ }^{42}$. Przez wiele lat po rzezi zdobytego przez wojska Batorego Sokoła, na mapach Litwy z nieistniejącej dawno twierdzy wciąż unosił się dym pożaru.

Niniejsza próba indeksacji i opisu korpusu nazewniczego Descriptio Ducatus Polocensis nie przynosi definitywnego rozwiązania wszystkich problemów związanych z tożsamością i położeniem każdej z oznaczonych i nazwanych na mapie miejscowości. Postanowiliśmy uznać za podstawową współczesną białoruską formę nazewniczą w transkrypcji na łacinkę. Nie udało się ustalić ponad wszelką wątpliwość tożsamości wszystkich toponimów. Zaproponowano dwie identyfikacje hipotetyczne (Budavičy-Budowicze, HalomysíHołomyśl), pod znakiem zapytania stoi również dokładne umiejscowienie twierdz Krasny-Krasne i Nieščarda-Nieszczerda, osad dziś nieistniejących, a poświadczonych w źródłach historycznych i kartograficznych (Kaliucina-Kolucino, Maly Haradok-Horodek Mały i Svirydavičy-Swirydowicze), wreszcie nazw miejscowych poświadczonych w hydronimach (Čarnica-Czernica oraz Maryniec) wszystkie te nazwy wyróżniono w indeksach asteriskiem. Co się tyczy hydronimów, wyznaczających schematycznie nakreśloną sieć wodną Połocczyzny, stwierdzono przypadki przeniesienia nazwy mniejszego dopływu na główny ciek wodny przedstawiony na mapie - Surazicza $\rightarrow$ Kasplia (r.)-Kaspla, Vswiaczicza $\rightarrow$ Uśviača (r./m.)Uświata oraz poświadczone w źródłach nazwy dawne - Oskaczicza $\rightarrow$ Čarniaŭka (r.)-Czerniawka, Ruczai $\rightarrow$ Lučosa (r.)-Łuczesa, Zerwani$c z a \rightarrow$ Čarnahosnica (r.)-Czarnogostnica. Stwierdzono wreszcie na-

42 J. Nieprzecki, J.T. Mayer, Magni Ducatus Lituaniae in suos Palatinatus et Districtus Divisus: Carte du Grand Duche de Lituaniae, Nürnberg 1749. Korzystam z egz. z Kolekcji dr. Tomasza Niewodniczańskiego, dep. Zamek Królewski w Warszawie - Muzeum, sygn. TN 1157. 

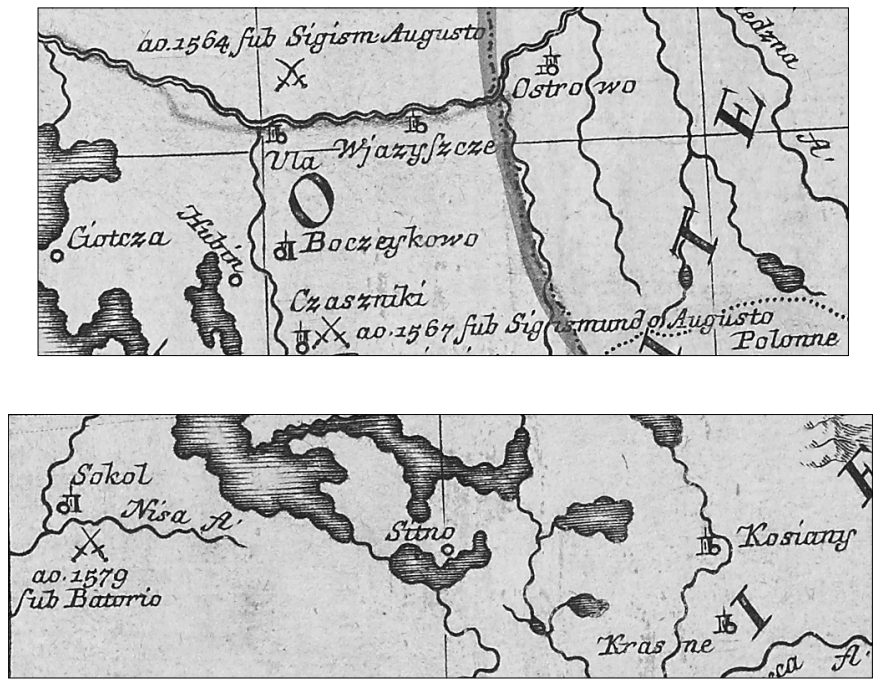

Il. 8-9. J. Nieprzecki, J.T. Mayer, Magni Ducatus Lituaniae in suos Palatinatus et Districtus Divisus: Carte du Grand Duche de Lituaniae, Nürnberg 1749 (Kolekcja dr. Tomasza Niewodniczańskiego, dep. Zamek Królewski w Warszawie - Muzeum, sygn. TN 1157, za uprzejmą zgodą Muzeum) fragmenty

zewniczy błąd kartografa lub rytownika: jest to przypadek toponimu Strzezewo $\rightarrow$ Stryžava-Stryżewo, umieszczonego przy lewym zamiast przy prawym dopływie rz. Ułły - Świeczy, blisko ujścia której widnieje z kolei pozbawiona nazwy miejscowość.

W naszym zamyśle cztery uzupełniające się indeksy umożliwić mają wszechstronne korzystanie $\mathrm{z}$ mapy Pachołowieckiego. INDEKS PODSTAwowy (I) zawiera zestawienie nazwy transliterowanej Z postaci występującej na mapie (N. translit.) z jej transkrypcją (N. transkr.) oraz nazwami w wersji polskiej, rosyjskiej i białoruskiej. Białoruska postać nazewnicza - w transkrypcji odpowiadającej standardom współczesnych normatywnych kompendiów białoruskich stanowi podstawę części opisowej (V): z wyjątkiem dwóch nazwanych na mapie miast, leżących dziś w granicach Federacji Rosyj- 
skiej (Siebież $\rightarrow$ Siebiež i Uświat $\rightarrow$ Usviaty), wszystkie miejscowości, rzeki i jeziora znajdują się na terenie dzisiejszej Białorusi ${ }^{43}$. INDEKS NAZW TRANSLITEROWYCH Z TRANSKRYPCJA BIALORUSKA (II) odsyła bezpośrednio od nazwy transliterowanej z mapy do części opisowej (V). Dalej następuje INDEKS BIAŁORUSKO-ROSYJSKI (III) rosyjska postać nazewnicza odsyła, tu i w części opisowej, od każdej nazwy miejscowej, z wyłączeniem nazw rzek oraz miejscowości o niewiadomym położeniu, do aktualnej mapy drogowej obwodu witebskiego ( $3 \cdots 36$ АБВГ $)^{44}$. Ostatni ze skorowidzów to odsyłający od transkrybowanych nazw białoruskich, a tym samym od części opisowej do polskiej postaci nazewniczej INDEKS BIAŁORUSKO-POLSKI (IV). Przy opracowywaniu indeksów i opisów posłużono się, prócz niezastąpionego Słownika geograficznego Królestwa Polskiego ${ }^{45}$ oraz szesnasto- i siedemnastowiecznych map Polski i Litwy, najnowszymi białoruskimi kompendiami historycznymi i nazewniczymi ${ }^{46}$,

43 Normatywne kompendia to, w zakresie toponimów: Назвы населеных пунктаў Рэспублікі Беларусь: Віцебская вобласць. Нарматьуины даведнік, У.М. Генкін, І.Л. Капылоў, В.П. Лемцюгова, пад рэд. В.П. Лемцюговай, Мінск 2009; hydronimów: Блакітная кніга Беларусі: Энцыклапедыя, рэдкал. Н.А. Дзісько, М.М. Курловіч, Я.В. Малашэвіч і інш., маст. В.Г. Загародні, Мінск 1994.

44 Витебская Область. Атлас автомобильньх дорог, Минск 2013 [skala: $1: 200000]$.

45 Słownik geograficzny Królestwa Polskiego i innych krajów słowiańskich, red. F. Sulimierski, B. Chlebowski, W. Walewski, t. 1-15, Warszawa 1880-1914; korzystam z wersji on-line: http://dir.icm.edu.pl/Slownik_geograficzny (dostęp: 17.07.2017).

46 Oprócz wymienionych wyżej leksykonów, korzystaliśmy z następujących prac: Вялікае Княства Літоўскае: Энцыклапедья, рэдкал. Г.П. Пашкоў (гал. рэд.) і інш.; маст. 3.Э. Герасімовіч, 2-е выд., т. 1-3, Мінск 2007-2010; Города, местечки и замки Великого Княжества Литовского. Энииклопедия, председ. Т.В. Белова, гл. ред. В.П. Саламаха, Минск 2009; Эниьклапедыя гісторы Беларусі, рэдкал. Г.П. Пашкоў і інш., маст. Э.Э. Жакевіч, т. 1-6, Мінск 19942003. Niezwykle użyteczna jest też mapa historyczna Wielkiego Księstwa Litewskiego Michaiła Spiridonaŭa (M. Спірыдонаў, Беларусь у другой палове XVI cm., карта 1: 1500 000, w: Нацьянальны атлас Беларусі, Мінск 2002, s. 266-267) 
a także źródłami internetowymi - między innymi pomocną w ustaleniu położenia miejscowości wikimapią (http://wikimapia.org), polsko-białorusko-rosyjską stroną http://radzima.net, zawierającą zindeksowane na podstawie dawnych map i spisów dane miejscowości z terenów Litwy i Białorusi, czy wreszcie cennym sprawozdaniem Instytutu Historii Petersburskiego Uniwersytetu Państwowego (SPBGU) z wyprawy badawczej mającej na celu odnalezienie i opisanie pozostałości drewnianych zamków Iwana IV Groźnego w ziemi połockiej ${ }^{47}$.

\section{Bibliografia}

Блакітная кніга Беларусі: Энцыклапедыя, рэдкал. Н.А. Дзісько, М.М. Курловіч, Я.В. Малашэвіч і інш., маст. В.Г. Загародні, Мінск 1994.

Вялікае Княства Літоускае: Энцыьклапедыя, рэдкал.: Г.П. Пашкоў (гал. рэд.) і інш.; маст. 3.Э. Герасімовіч, 2-е выд., т. 1-3, Мінск 2007-2010.

Города, местечки и замки Великого Княжества Литовского. Энциклопедия, председ. Т.В. Белова, гл. ред. В.П. Саламаха, Минск 2009.

Иван Грозный - завоеватель Полоцка (новые документы по истории Ливонской войны), сост., подгот. к публ., вступ. ст. В.Ю. Ермак, описание рукописи К.Ю. Ерусалимский, послесл. А.И. Филюшкин, „Три столетия Восточной Европы (XV-XVII вв.). Серия изданий источников", т. 1, Санкт-Петербург 2014.

Назвы населеных пунктаў Рэспублікі Беларусь: Віцебская вобласиь. Нарматыўны даведнік, У.М. Генкін, І.Л. Капылоў, В.П. Лемцюгова, пад рэд. В.П. Лемцюговай, Мінск 2009.

opatrzona wykazem miejscowości (brak hydronimów) w podwójnej wersji - historycznej („ruskiej”, a w ich braku współczesnej białoruskiej) oraz białoruskiej.

47 А.И. Филюшкин, А.Н. Лобин, А.В. Кузьмин, И.А. Прохоренков, П.А. Толмачев, Д.А. Бессуднов, К.С. Жарикова, Полоикая земля как контактная зона при Иване Грозном, 1563-1579 г2. - экспедиция 18-25 июля 2015 г., http://history.spbu.ru/nauka/nauchnye-tsentry/285-rgnf-pogranichie-2015/ ekspeditsii/910-polotskaya-zemlya-kak-kontaktnaya-zona-pri-ivane-groznom1563-1579-gg-ekspeditsiya-18-25-iyulya-2015-g.html (dostęp: 27.08.2017). 
Писцовая книга Полоцка и Полоцкого повета, w: Писиовые книги Московского государства, ч. 1, отд. 2, под ред. Н.В. Калачева, Санкт-Петербург 1877, s. $421-566$.

Спірыдонаў М., Беларусь на карие Вялікага Княства Літоўскага 1613 г., „Гістарычны Альманах” 8 (2003), s. 3-55.

Спірыдонаў М., Беларусь у другой палове XVI cm., карта 1: 1500 000, w: Нацыянальны атлас Беларусі, Мінск 2002, s. 266-267.

Филюшкин А.И., Лобин А.Н., Кузьмин А.В., Прохоренков И.А., Толмачев П.А., Бессуднов Д.А., Жарикова К.С., Полочкая земля как контактная зона при Иване Грозном, 1563-1579 г2. - экспедиция 18-25 июля 2015 г., http://history. spbu.ru/nauka/nauchnye-tsentry/285-rgnf-pogranichie-2015/ekspeditsii/910-polotskaya-zemlya-kak-kontaktnaya-zona-pri-ivane-groznom-1563-1579-gg-ekspeditsiya-18-25-iyulya-2015-g.html (dostęp: 27.08.2017).

Энизыклапедыя гісторыі Беларусі, рэдкал. Г.П. Пашкоў і інш., маст. Э.Э. Жакевіч, т. 1-6, Мінск 1994-2003.

Alexandrowicz S., Kartografia Wielkiego Księstwa Litewskiego od XV do połowy XVIII wieku, Warszawa 2012.

Alexandrowicz S., Mapa Wielkiego Księstwa Litewskiego Tomasza Makowskiego z 1613 r. tzw. „radziwiłłowska”, jako źródło do dziejów Litwy i Białorusi, „Studia Źródłoznawcze” 10 (1965), s. 33-67.

Alexandrowicz S., Źródła kartograficzne do wyprawy połockiej Stefana Batorego roku 1579, w: Od armii komputowej do narodowej (XVI-XX w.), red. Z. Karpus, W. Rezmer, Toruń 1998, s. 17-43.

Alexandrowicz S., Łuczyński J., Skrycki R., Historia kartografii ziem polskich do XVIII wieku, Warszawa 2017.

Blaeu J., Magni Ducatus Lithuaniae et regionum adiacentium exacta descriptio, Amsterdam 1648, Kolekcja dr. Tomasza Niewodniczańskiego, dep. Zamek Królewski w Warszawie - Muzeum, sygn. TN 1130.

Buczek K., Dorobek kartograficzny wojen Stefana Batorego, „Wiadomości Służby Geograficznej" 8 (1934), z. 3, s. 3-16.

Buczek K., Dzieje kartografii polskiej od XV do XVIII wieku. Zarys analityczno-syntetyczny, Wrocław 1963.

Buczek K., Kartografia polska w czasach Stefana Batorego, „Wiadomości Służby Geograficznej" 7 (1933), z. 2, s. 69-121.

Franczak G., Atlas Księstwa Połockiego Stanisława Pachołowieckiego z 1580 roku transkrypcja i przekład, „Terminus” 19 (2017), z. 1 (42), s. 61-74.

Franczak G., Polotia recepta. Mapa Księstwa Połockiego jako tekst propagandowy (w przygotowaniu).

Franczak G., Rzymski łącznik: Giovanni Battista Cavalieri (1525-1601), rytownik Hozjusza i Tretera (w przygotowaniu).

Górski K., Tekstologia i edytorstwo dzieł literackich, Toruń 2011. 
Gruchała J., Tekstologia wyłożona „modo Italico” (O książce Alfredo Stussiego „Wprowadzenie do edytorstwa $i$ tekstologii”), „Wielogłos. Pismo Wydziału Polonistyki UJ” 2012, nr 3 (13), s. 265-272.

Grześkowiak R., Komentarz edytorski, II. Uwagi do tekstu, w: K. Twardowski, Lekcyje Kupidynowe, wyd. R. Grześkowiak, Warszawa 1997 (Biblioteka Pisarzy Staropolskich, t. 7)

Harley J.B., The New Nature of Maps. Essays in the History of Cartography, ed. by P. Laxton, Baltimore 2001.

Kozica K., Charakterystyka prac kartograficznych Stanisława Pachołowieckiego (1580), „Terminus” 19 (2017), z. 1 (42), s. 37-59.

Loth R., Podstawowe pojęcia i problemy tekstologii i edytorstwa naukowego, Warszawa 2006.

Łopatecki K., Mapy w planowaniu działań operacyjnych armii polskiej i litewskiej do początków panowania Stefana Batorego, „Terminus” 19 (2017), z. 3 (44), s. 567-607.

Łopatecki K., Okoliczności powstania i przydatność wojskowa mapy Descriptio Ducatus Polocensis Stanisława Pachołowieckiego (1580), „Terminus” 19 (2017), z. 1 (42), s. 75-126.

Łopatecki K., Ryciny prezentujące kampanię połockg 1579 roku jako jednolita kompozycja kartograficzna, „Terminus” 19 (2017), z. 1 (42), s. 157-191.

Łuczyński J., Rzeczpospolita na mapach kartografów zachodnioeuropejskich z XVII i pierwszej połowy XVIII w., w: S. Alexandrowicz, J. Łuczyński, R. Skrycki, Historia kartografii ziem polskich do XVIII wieku, Warszawa 2017, s. 126-149.

Łuczyński J., Ziemie polskie w kartografii drugiej połowy XVI wieku, w: S. Alexandrowicz, J. Łuczyński, R. Skrycki, Historia kartografii ziem polskich do XVIII wieku, Warszawa 2017, s. 83-110.

Maas P., Krytyka tekstu. Fragmenty, przeł. K. Sybilska, „Pamiętnik Literacki” 85 (1994), z. 2, s. 188-206.

Maas P., Textkritik, 4 Aufl., Leipzig 1960.

Maas P., Textual Criticism, Oxford 1958.

Makowski T., Strubicz M., Magni Ducatus Lithuaniae caeterarumque regionum illi adiacentium exacta descriptio, Amsterdam 1613, egz. Herzogin Anna-Amalia Bibliothek w Weimarze, sygn. Kt 237-201 S.

Makowski T., Strubicz M., Magni Ducatus Lithuaniae caeterarumque regionum illi adiacentium exacta descriptio, [Amsterdam 1631], egz. z Kolekcji dr. Tomasza Niewodniczańskiego, dep. Zamek Królewski w Warszawie - Muzeum, sygn. TN 1141.

Mercator G., Lithuania, w: idem, Atlas sive Cosmographicae meditationes de fabrica mundi et fabricati figura, Duisburg 1595, tab. XXVII, egz. z Kolekcji dr. Tomasza Niewodniczańskiego, dep. Zamek Królewski w Warszawie - Muzeum, sygn. TN 1127. 
Niedźwiedź J., Atlas Księstwa Połockiego Stanisława Pachołowieckiego (1580): propaganda, genologia i tworzenie wiedzy geograficznej, „Terminus” 19 (2017), z. 1 (42), s. 127-155.

Nieprzecki J., Mayer J. T., Magni Ducatus Lituaniae in suos Palatinatus et Districtus Divisus: Carte du Grand Duche de Lituaniae, Nürnberg 1749, egz. z Kolekcji dr. Tomasza Niewodniczańskiego, dep. Zamek Królewski w Warszawie - Muzeum, sygn. TN 1157.

Pachołowiecki S., Cavalieri G.B., Descriptio Ducatus Polocensis, Roma 1580, egz. z Kolekcji dr. Tomasza Niewodniczańskiego, dep. Zamek Królewski w Warszawie - Muzeum, sygn. TN 2464.

Pasquali G., Storia della tradizione e critica del testo, Firenze 1988.

Schilder G., Monumenta Cartografica Neerlandica, vol. 9: Hessel Gerritsz (1580/811632). Master Engraver and Map Maker, Who 'Ruled' the Seas, Houten 2013.

Słownik geograficzny Królestwa Polskiego i innych krajów słowiańskich, red. F. Sulimierski, B. Chlebowski, W. Walewski, t. 1-15, Warszawa 1880-1914.

Strubicz M., Magni Ducatus Lithuaniae, Livoniae et Moscoviae descriptio, Köln 1589, egz. z Kolekcji dr. Tomasza Niewodniczańskiego, dep. Zamek Królewski w Warszawie - Muzeum, sygn. TN 2456.

Stussi A., Introduzione agli studi di filologia italiana, Bologna 2002.

Stussi A., Wprowadzenie do edytorstwa i tekstologii, przeł. M. i P. Salwa, Gdańsk 2011.

Sulimowski S., [Rękopiśmienna mapa operacyjna kampanii połockiej i wielkołuckiej], Archivio Segreto Vaticano, Segreteria di Stato, Polonia, sygn. 15A, k. 88.

Timpanaro S., La genesi del metodo del Lachmann, Torino 2004.

Timpanaro S., The Genesis of Lachmann's Method, ed. and transl. by G.W. Most, Chicago 2005.

Twardowski K., Lekcyje Kupidynowe, wyd. R. Grześkowiak, Warszawa 1997 (Biblioteka Pisarzy Staropolskich, t. 7). 


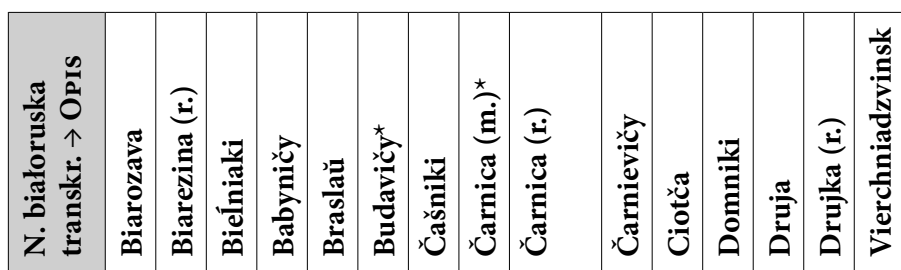

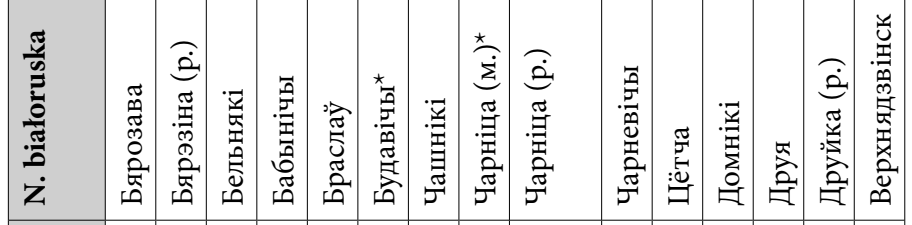

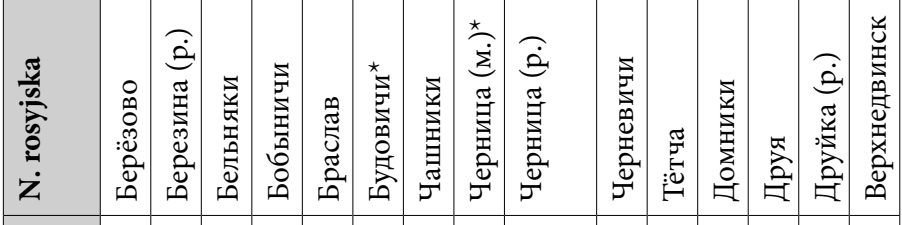

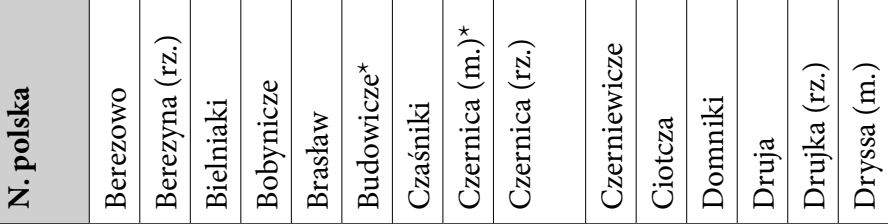

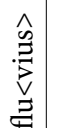

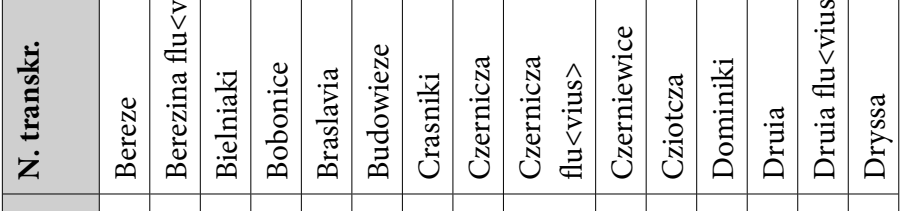

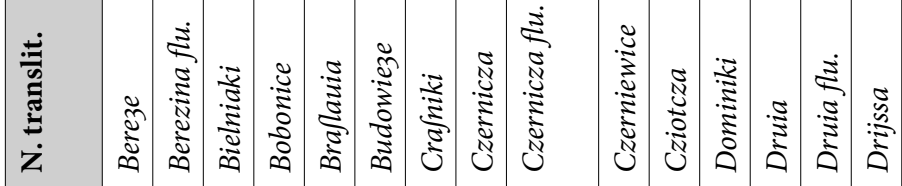




\begin{tabular}{|c|c|c|c|c|c|c|c|c|c|c|c|c|c|c|c|c|}
\hline & & 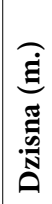 & 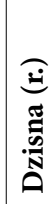 & 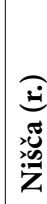 & 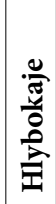 & 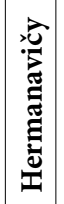 & 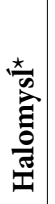 & 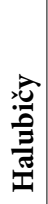 & 离 & 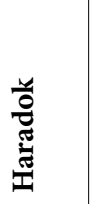 & 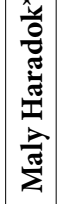 & 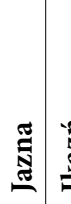 & & 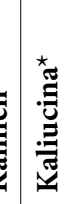 & & 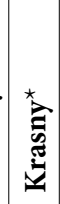 \\
\hline & 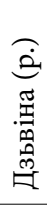 & 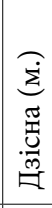 & 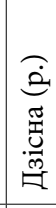 & $\begin{array}{l}\text { فे } \\
\text { 舀 } \\
\text { 定 }\end{array}$ & 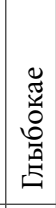 & 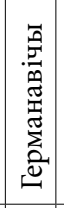 & 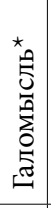 & 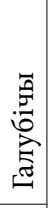 & 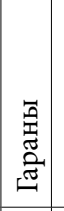 & 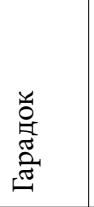 & 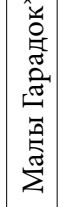 & 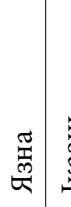 & & 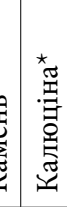 & & 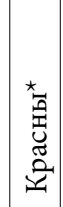 \\
\hline$\dot{0}$ & 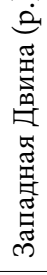 & 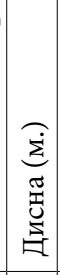 & 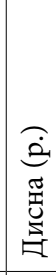 & 空 & 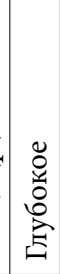 & 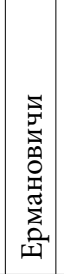 & 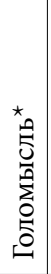 & 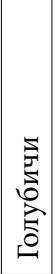 & 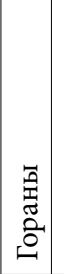 & $\begin{array}{l}\text { 兑 } \\
\text { ò } \\
\text { aे }\end{array}$ & 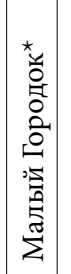 & & & 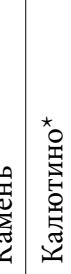 & & 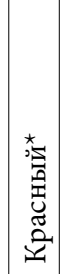 \\
\hline 5 & 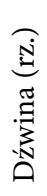 & 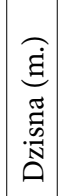 & 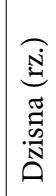 & 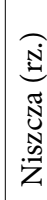 & 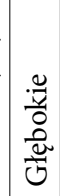 & 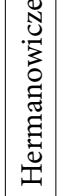 & 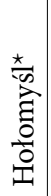 & 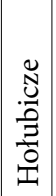 & 鸽 & 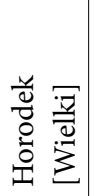 & 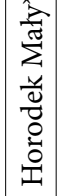 & & & 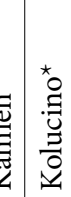 & & 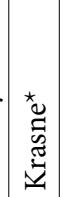 \\
\hline $\begin{array}{l}\hat{0} \\
\text { 官 }\end{array}$ & 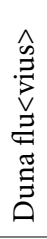 & 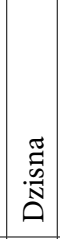 & 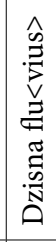 & 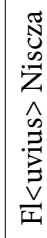 & 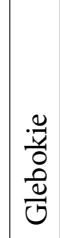 & 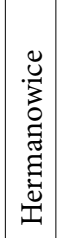 & 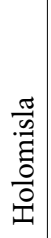 & 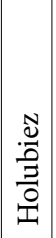 & 氙 & 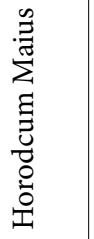 & 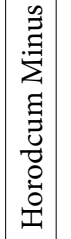 & & & $\frac{5}{5}$ & & 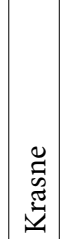 \\
\hline $\begin{array}{l}\tilde{s} \\
\tilde{b} \\
:=\end{array}$ & $\begin{array}{l}\frac{\pi}{2} \\
3 \\
a\end{array}$ & 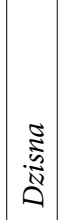 & 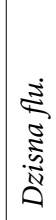 & 胥 & 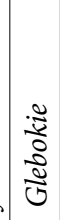 & 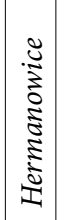 & $I$ & $\frac{\mathfrak{s}}{3}$ & 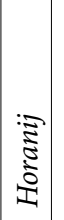 & $\bar{z}$ & 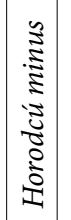 & & 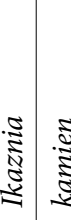 & $\stackrel{\Sigma}{\Sigma}$ & & 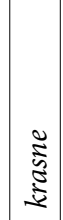 \\
\hline
\end{tabular}




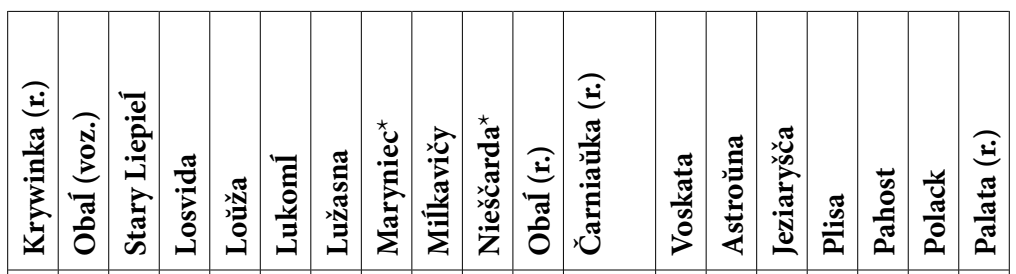

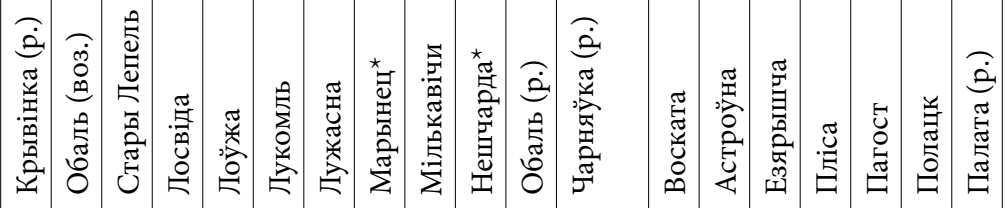

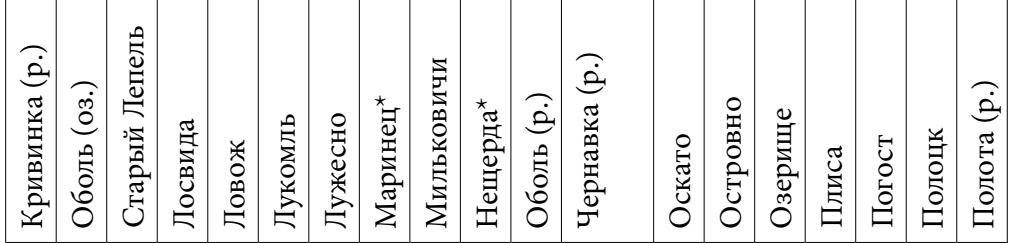

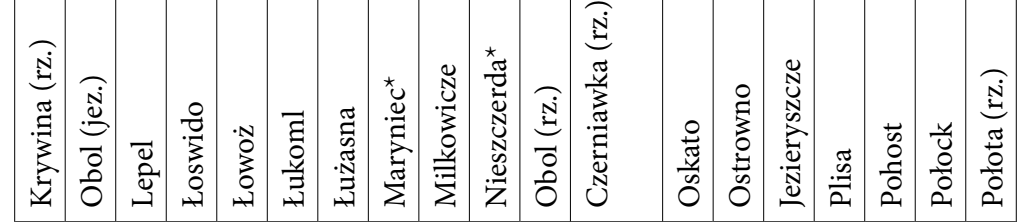

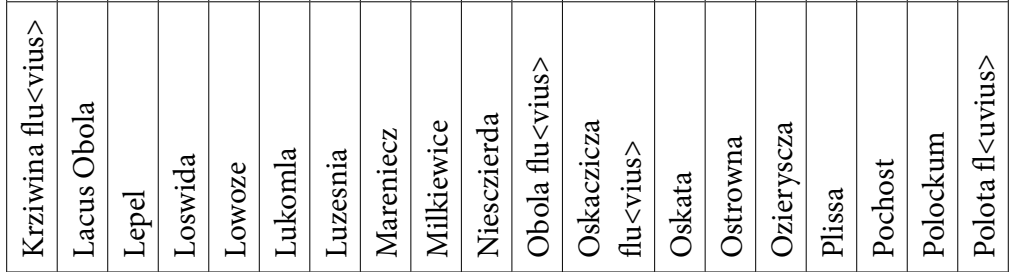

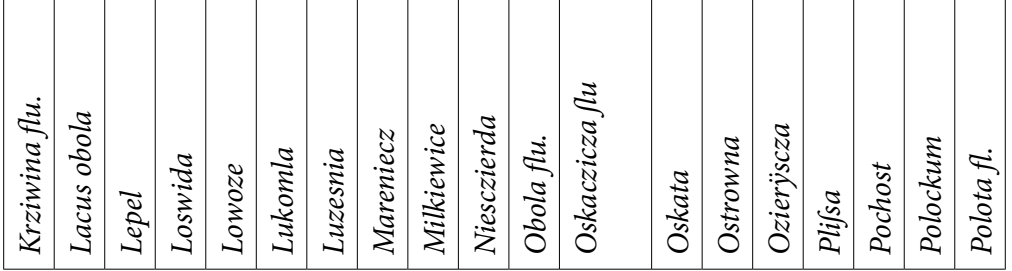




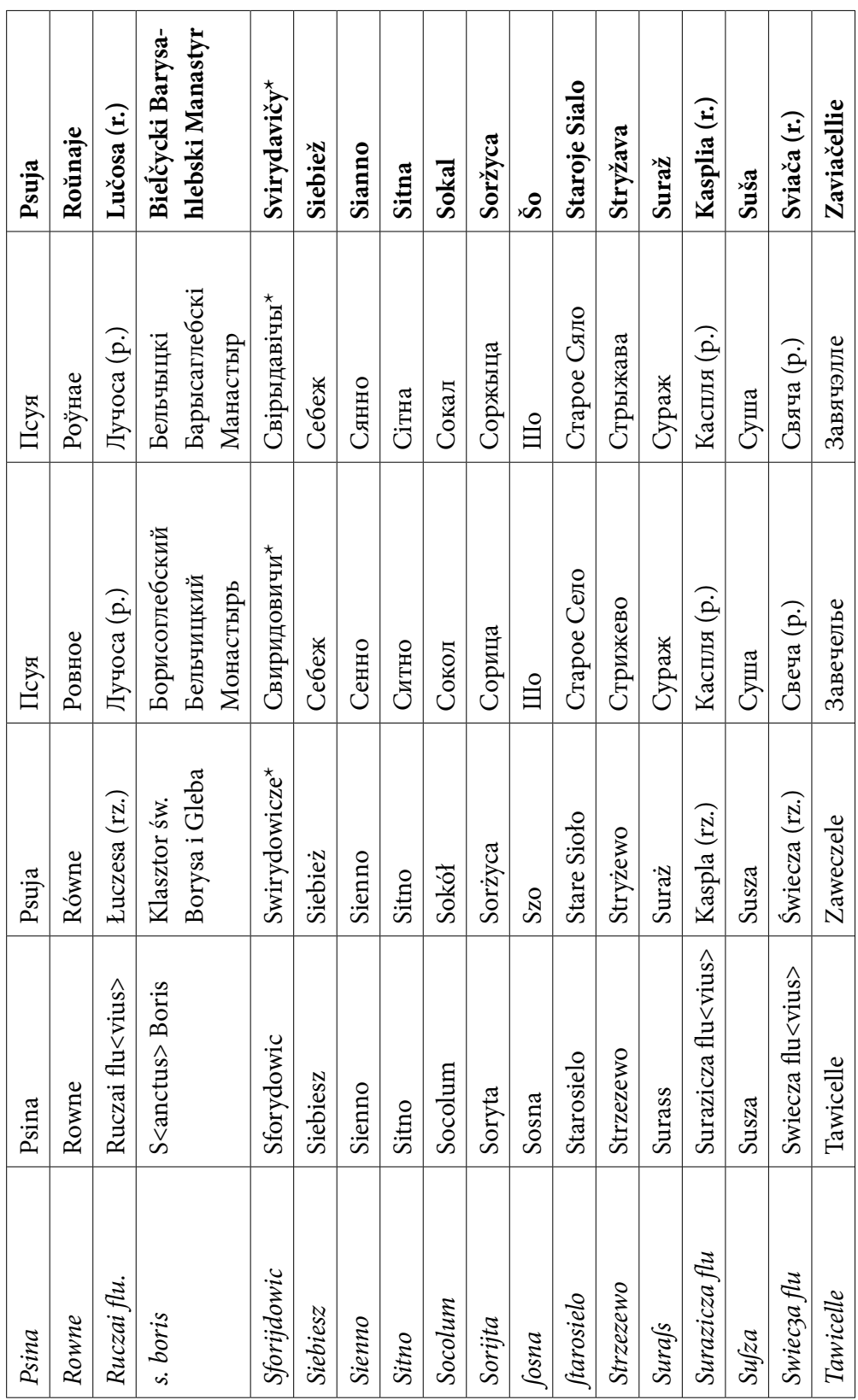




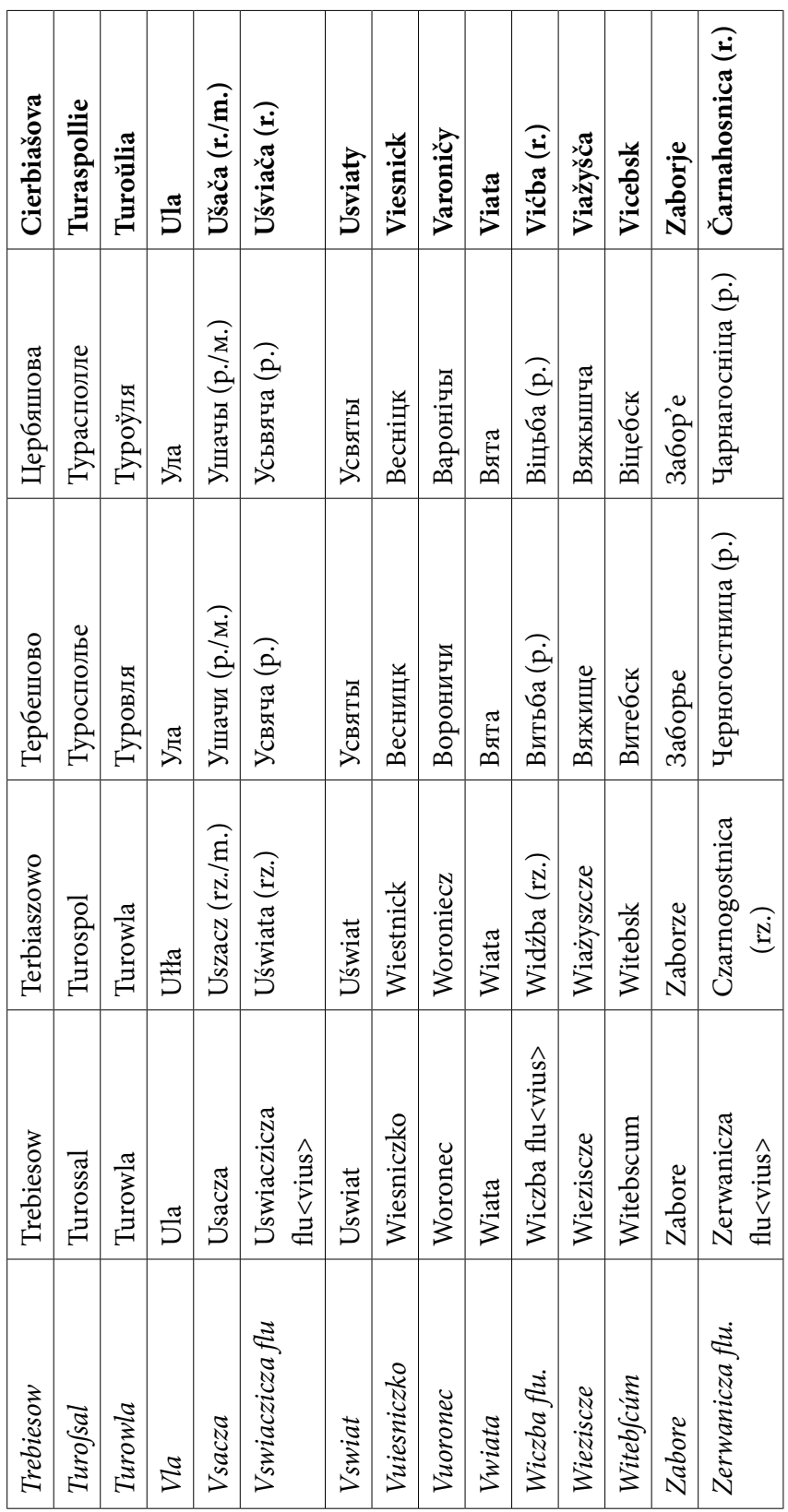




\section{INDEKS NAZW TRANSLITEROWYCH Z TRANSKRYPCJĄ BIALORUSKA}

\begin{tabular}{|c|c|}
\hline N. translit. & N. białoruska transkr. $\rightarrow$ OPIs \\
\hline Bereze & Biarozava \\
\hline Berezina flu. & Biarezina (r.) \\
\hline Bielniaki & Biếniaki \\
\hline Bobonice & Babyničy \\
\hline Braflauia & Braslaŭ \\
\hline Budowieze & Budavičy $^{*}$ \\
\hline Crafniki & Čašniki \\
\hline Czernicza & Čarnica $(\mathbf{m} .)^{*}$ \\
\hline Czernicza flu. & Čarnica (r.) \\
\hline Czerniewice & Čarnievičy \\
\hline Cziotcza & Ciotča \\
\hline Dominiki & Domniki \\
\hline Druia & Druja \\
\hline Druia flu. & Drujka (r.) \\
\hline Drijssa & Vierchniadzvinsk \\
\hline Drijssa flu. & Drysa (r.) \\
\hline DVNA FLV. & Dzvina (r.) \\
\hline Dzisna & Dzisna (m.) \\
\hline Dzisna flu. & Dzisna (r.) \\
\hline fl. niscza & Nišča (r.) \\
\hline Glebokie & Hlybokaje \\
\hline Hermanowice & Hermanavičy \\
\hline Holomifla & Halomysi ${ }^{*}$ \\
\hline Holubiez & Halubičy \\
\hline Horanij & Harany \\
\hline Horodcú maius & Haradok \\
\hline Horodcú minus & Maly Haradok ${ }^{\star}$ \\
\hline
\end{tabular}




\begin{tabular}{|c|c|}
\hline Iasnij & Jazna \\
\hline Ikaznia & Ikazń \\
\hline kamien & Kamień \\
\hline kieluta & Kaliucina $^{*}$ \\
\hline kosian & Kaziany \\
\hline krasne & Krasny* \\
\hline Krziwina flu. & Krywinka (r.) \\
\hline Lacus obola & Obali (voz.) \\
\hline Lepel & Stary Liepieĺ \\
\hline Loswida & Losvida \\
\hline Lowoze & Loǔža \\
\hline Lukomla & Lukomí \\
\hline Luzesnia & Lužasna \\
\hline Mareniecz & Maryniec $^{\star}$ \\
\hline Milkiewice & Milikavičy \\
\hline Niesczierda & Nieščarda* \\
\hline Obola flu. & Obal (r.) \\
\hline Oskaczicza $\int \mathrm{lu}$ & Čarniaŭka (r.) \\
\hline Oskata & Voskata \\
\hline Ostrowna & Astroŭna \\
\hline Ozierÿscza & Jeziaryšča \\
\hline Plifsa & Plisa \\
\hline Pochost & Pahost \\
\hline Polockum & Polack \\
\hline Polota fl. & Palata (r.) \\
\hline Psina & Psuja \\
\hline Rowne & Roŭnaje \\
\hline Ruczai flu. & Lučosa (r.) \\
\hline s. boris & Bieĺčycki Barysahlebski Manastyr \\
\hline Sforijdowic & Svirydavičy ${ }^{\star}$ \\
\hline Siebiesz & Siebiež \\
\hline Sienno & Sianno \\
\hline
\end{tabular}




\begin{tabular}{|l|l|}
\hline Sitno & Sitna \\
\hline Socolum & Sokal \\
\hline Sorijta & Soržyca \\
\hline Sosna & Šo \\
\hline ftarosielo & Staroje Sialo \\
\hline Strzezewo & Stryžava \\
\hline Surafs & Suraž \\
\hline Surazicza flu & Kasplia $(\mathbf{r}$ ) \\
\hline Sufza & Suša \\
\hline Swiecza flu & Sviača $(\mathbf{r}$ ) \\
\hline Tawicelle & Zaviačellie \\
\hline Trebiesow & Cierbiašova \\
\hline Turofsal & Turaspollie \\
\hline Turowla & Turoŭlia \\
\hline Vla & Ula \\
\hline Vsacza & Ušača (r./m.) \\
\hline Vswiaczicza flu & Uśviača (r.) \\
\hline Vswiat & Usviaty \\
\hline Vuiesniczko & Viesnick \\
\hline Vuoronec & Varoničy \\
\hline Vwiata & Viata \\
\hline Wiczba flu. & Vićba (r.) \\
\hline Wieziscze & Viažyšča \\
\hline Witebfcúm & Vicebsk \\
\hline Zabore & Zaborje \\
\hline Zerwanicza flu. & Čarnahosnica (r.) \\
\hline & \\
\hline
\end{tabular}




\section{INDEKS BIAEORUSKO-ROSYJSKI}

\begin{tabular}{|c|c|}
\hline N. białoruska transkr. & N. rosyjska \\
\hline Astroŭna & Островно 27 Б \\
\hline Babyničy & Бобыничи 15 г \\
\hline Biarezina (r.) & Березина (р.) \\
\hline Biarozava & Берёзово 25 Б \\
\hline Bieĺčycki Barysahlebski Manastyr & $\begin{array}{l}\text { Борисоглебский Бельчицкий } \\
\text { монастырь }\end{array}$ \\
\hline Biel̂niaki & Бельняки $33 \mathrm{~A}$ \\
\hline Braslaŭ & Браслав ${ }^{13 \mathrm{~A}}$ \\
\hline Budavičy $^{\star}$ & Будовичи* \\
\hline Čarnahosnica (r.) & Черногостница (р.) \\
\hline Čarniaŭka (r.) & Чернавка (р.) \\
\hline Čarnica $(\mathbf{m} .)^{\star}$ & Черница (м. $)^{* 18 \text { в }}$ \\
\hline Čarnica (r.) & Черница (р.) \\
\hline Čarnievičy & Черневичи 15 в \\
\hline Čašniki & Чашники 26в \\
\hline Cierbiašova & Тербешово 27 в \\
\hline Ciotča & Тётча ${ }^{16 \Gamma}$ \\
\hline Domniki & Домники ${ }^{17 \mathrm{~A}}$ \\
\hline Druja & Друя ${ }^{5 \Gamma}$ \\
\hline Drujka (r.) & Друйка (р.) \\
\hline Drysa (r.) & Дрисса (р.) \\
\hline Dzisna (m.) & Дисна (м.) ${ }^{15 \mathrm{~A}}$ \\
\hline Dzisna (r.) & Дисна (р.) \\
\hline Dzvina (r.) & Западная Двина (р.) \\
\hline Halomysi ${ }^{*}$ & Голомысль ${ }^{\star}$ \\
\hline Halubičy & Голубичи 23 Б \\
\hline Haradok & Городок ${ }^{18 \Gamma}$ \\
\hline Harany & Гораны ${ }^{17 \text { в }}$ \\
\hline Hermanavičy & Ермановичи ${ }^{14 \text { г }}$ \\
\hline
\end{tabular}




\begin{tabular}{|c|c|}
\hline Hlybokaje & Глубокое 23 А \\
\hline Ikazń & Иказнь ${ }^{13 \text { Б }}$ \\
\hline Jazna & Язно ${ }^{15 \text { в }}$ \\
\hline Jeziaryšča & Озерище ${ }^{10 ~ \Gamma ~}$ \\
\hline Kaliucina ${ }^{*}$ & Калютино* \\
\hline Kamień & Камень 25 Б \\
\hline Kasplia (r.) & Каспля (р.) \\
\hline Kaziany & Козяны ${ }^{18 \mathrm{~A}}$ \\
\hline Krasny $^{\star}$ & Красный 16г,25 Б \\
\hline Krywinka (r.) & Кривинка (р.) \\
\hline Losvida & Большое Лосвида 18 г \\
\hline Loǔža & Ловож ${ }^{17 \Gamma}$ \\
\hline Lučosa (r.) & Лучоса (p.) \\
\hline Lukomí & Лукомль 32 Б \\
\hline Lužasna & Лужесно 19 в \\
\hline Maly Haradok ${ }^{\star}$ & Малый Городок* \\
\hline Maryniec $^{*}$ & Маринец* \\
\hline Miĺkavičy & Мильковичи ${ }^{27 \mathrm{~A}}$ \\
\hline Nieščarda $^{*}$ & Нещерда ${ }^{*}$ \\
\hline Nišča (r.) & Нища (р.) \\
\hline Obali (r.) & Оболь (р.) \\
\hline Obaí (voz.) & Оболь (оз.) ${ }^{18 \mathrm{~A}}$ \\
\hline Pahost & Погост ${ }^{13 \mathrm{~b}}$ \\
\hline Palata (r.) & Полота (р.) \\
\hline Plisa & Плиса ${ }^{14 \text { г }}$ \\
\hline Polack & Полоцк 16 АБвГ \\
\hline Psuja & Псуя 24 А \\
\hline Roŭnaje & Ровное ${ }^{17 \Gamma}$ \\
\hline Sianno & Сенно ${ }^{27 \text { в }}$ \\
\hline Siebiež & Себеж \\
\hline Sitna & Ситно ${ }^{17 \text { Б }}$ \\
\hline Šo & Шо $^{24 \mathrm{~A}}$ \\
\hline
\end{tabular}




\begin{tabular}{|c|c|}
\hline Sokal & Сокол $^{7 \mathrm{r}}$ \\
\hline Soržyca & Сорица ${ }^{27 \mathrm{~A}}$ \\
\hline Staroje Sialo & Старое Село 27 Б \\
\hline Stary Liepiel & Старый Лепель 25 в \\
\hline Stryžava & Стрижево 26 Б \\
\hline Suraž & Сураж ${ }^{20 \text { в }}$ \\
\hline Suša & Суша $25 \mathrm{5}$ \\
\hline Sviača (r.) & Свеча (р.) \\
\hline Svirydavičy* & Свиридовичи* \\
\hline Turaspollie & Туросполье 25 Б \\
\hline Turoŭlia & Туровля 16г \\
\hline Ula & Ула \\
\hline Ušača (r./m.) & Ушачи (р./м.) ${ }^{25 \mathrm{~A}}$ \\
\hline Usviaty & Усвяты \\
\hline Uśviača (r.) & Усвяча (р.) \\
\hline Varoničy & Вороничи 16в \\
\hline Viata & Вята ${ }^{6 \mathrm{~B}}$ \\
\hline Viažyšča & Вяжище е $27 \mathrm{~A}$ \\
\hline Vicebsk & Витебск 28 АБ \\
\hline Vićba (r.) & Витьба (р.) \\
\hline Vierchniadzvinsk & Верхнедвинск бг \\
\hline Viesnick & Весницк 24 Б \\
\hline Voskata & Оскато ${ }^{18 \text { 5 }}$ \\
\hline Zaborje & Заборье 23 в \\
\hline Zaviačellie & Завечелье 25 A \\
\hline
\end{tabular}




\section{INDEKS BIALORUSKO-POLSKI}

\begin{tabular}{|c|c|}
\hline N. białoruska transkr. & N. polska \\
\hline Astroŭna & Ostrowno \\
\hline Babyničy & Bobynicze \\
\hline Biarezina (r.) & Berezyna (rz.) \\
\hline Biarozava & Berezowo \\
\hline Bieĺčycki Barysahlebski Manastyr & Klasztor św. św. Borysa i Gleba \\
\hline Bieĺniaki & Bielniaki \\
\hline Braslaŭ & Brasław \\
\hline Budavičy ${ }^{\star}$ & Budowicze $^{*}$ \\
\hline Čarnahosnica (r.) & Czarnogostnica (rz.) \\
\hline Čarniaŭka (r.) & Czerniawka (rz.) \\
\hline Čarnica $(\mathbf{m} .)^{\star}$ & Czernica $(\mathrm{m} .)^{*}$ \\
\hline Čarnica (r.) & Czernica (rz.) \\
\hline Čarnievičy & Czerniewicze \\
\hline Čašniki & Czaśniki \\
\hline Cierbiašova & Terbiaszowo \\
\hline Ciotča & Ciotcza \\
\hline Domniki & Domniki \\
\hline Druja & Druja \\
\hline Drujka (r.) & Drujka (rz.) \\
\hline Drysa (r.) & Dryssa (rz.) \\
\hline Dzisna (m.) & Dzisna (m.) \\
\hline Dzisna (r.) & Dzisna (rz.) \\
\hline Dzvina (r.) & Dźwina (rz.) \\
\hline Halomysí ${ }^{\star}$ & Hołomyśl ${ }^{*}$ \\
\hline Halubičy & Hołubicze \\
\hline Haradok & Horodek [Wielki] \\
\hline Harany & Horany \\
\hline Hermanavičy & Hermanowicze \\
\hline
\end{tabular}




\begin{tabular}{|c|c|}
\hline Hlybokaje & Głębokie \\
\hline Ikazń & Ikaźń \\
\hline Jazna & Jazno \\
\hline Jeziaryšča & Jezieryszcze \\
\hline Kaliucina $^{*}$ & Kolucino ${ }^{*}$ \\
\hline Kamień & Kamień \\
\hline Kasplia (r.) & Kaspla (rz.) \\
\hline Kaziany & Koziany \\
\hline Krasny $^{\star}$ & Krasne $^{*}$ \\
\hline Krywinka (r.) & Krywina (rz.) \\
\hline Losvida & Łoswido \\
\hline Loǔža & Łowoż \\
\hline Lučosa (r.) & Euczesa (rz.) \\
\hline Lukomí & Łukoml \\
\hline Lužasna & Łużasna \\
\hline Maly Haradok ${ }^{\star}$ & Horodek Mały* \\
\hline Maryniec $^{*}$ & Maryniec ${ }^{*}$ \\
\hline Miĺkavičy & Milkowicze \\
\hline Nieščarda $^{*}$ & Nieszczerda* \\
\hline Nišča (r.) & Niszcza (rz.) \\
\hline Obali (r.) & Obol (rz.) \\
\hline Obaî (voz.) & Obol (jez.) \\
\hline Pahost & Pohost \\
\hline Palata (r.) & Połota (rz.) \\
\hline Plisa & Plisa \\
\hline Polack & Połock \\
\hline Psuja & Psuja \\
\hline Roŭnaje & Równe \\
\hline Sianno & Sienno \\
\hline Siebiež & Siebież \\
\hline Sitna & Sitno \\
\hline Šo & Szo \\
\hline
\end{tabular}




\begin{tabular}{|l|l|}
\hline Sokal & Sokół \\
\hline Soržyca & Sorżyca \\
\hline Staroje Sialo & Stare Sioło \\
\hline Stary Liepiel & Lepel \\
\hline Stryžava & Stryżewo \\
\hline Suraž & Suraż \\
\hline Suša & Susza \\
\hline Sviača (r.) & Swiecza (rz.) \\
\hline Svirydavičy ${ }^{*}$ & Swirydowicze \\
\hline Turaspollie & Turospol \\
\hline Turoǔlia & Turowla \\
\hline Ula & Ułła \\
\hline Ušača (r./m.) & Uszacz (rz./m.) \\
\hline Usviaty & Uświat \\
\hline Uśviača (r.) & Uświata (rz.) \\
\hline Varoničy & Woroniecz \\
\hline Viata & Wiata \\
\hline Viažyšča & Wiażyszcze \\
\hline Vicebsk & Witebsk \\
\hline Vićba (r.) & Widźba (rz.) \\
\hline Vierchniadzvinsk & Dryssa (m.) \\
\hline Viesnick & Wiestnick \\
\hline Voskata & Oskato \\
\hline Zaborje & Zaborze \\
\hline Zaviačellie & Zaweczele \\
\hline & \\
\hline
\end{tabular}




\section{OPIS}

Astroŭna - Ostrowno, miasteczko około $25 \mathrm{~km}$ na południowy zachód od Witebska ( $\rightarrow$ Vicebsk), z zamkiem założonym przez wojewodę witebskiego Iwana Sapiehę w latach 20. XVI wieku ${ }^{27}$.

Babyničy - Bobynicze, osada nad jeziorem Bobyno, ok $40 \mathrm{~km}$ na południowy zachód od Połocka ${ }^{15}$.

Biarezina (r.) - Berezyna, prawy dopływ Dniepru (613 km biegu), źródła nieopodal miejscowości Dokszyce (Dokšycy), około $115 \mathrm{~km}$ na południowy zachód od Połocka, ujście na północ od m. Rzeczyca (Rečyca).

Biarozava - Berezowo, osada na zachodnim brzegu jeziora Berezowskiego (Biarozaŭskaje), około $40 \mathrm{~km}$ na południe od Połocka ${ }^{25}$.

Bieĺčycki Barysahlebski Manastyr - nieistniejący dziś klasztor męski pw. św. św. Borysa i Gleba w Bielczycach (Bieĺčycy) na lewym brzegu Dźwiny, obecnie w granicach Połocka. Ufundowany na początku XII wieku przez księcia połockiego Borysa-Rogwołoda Wsiesławowicza, był jednym z ważniejszych ufortyfikowanych miejsc na południowej flance stolicy księstwa. W lutym 1563 roku stacjonował tam oblegający miasto Iwan IV Groźny.

Bieĺniaki - Bielniaki, osada nad rz. Uświejką (Usviejka), prawym dopływem rzeki Ułły (Ula), około $90 \mathrm{~km}$ na południowy zachód od Witebska ( $\rightarrow$ Vicebsk) ${ }^{33 \mathrm{~A}}$.

Braslaŭ - Brasław, miasto i zamek nad jeziorem Drywiaty (Dryviaty), na szlaku inflanckim - około $120 \mathrm{~km}$ na północny zachód od Połocka i niecałe $50 \mathrm{~km}$ na południowy wschód od Dyneburga (Daugavpils) ${ }^{13 \mathrm{~A}}$.

Budavičy ${ }^{\star}$ - Budowicze, nieistniejąca dziś osada nad rzeką Budowieść (Budaviesć), wypływającą z jeziora Łobaż i uchodzącą do rzeką Obol ( $\rightarrow$ Obaĺ) na zachód od dzisiejszej wsi Spaskaje.

Čarnahosnica (r.) - Czarnogostnica, odpowiada najpewniej rzece oznaczonej na mapie Pachołowieckiego jako Zerwanicza, lewy dopływ Dźwiny, do której uchodzi we wsi Wiażyszcze ( $\rightarrow$ Viažyšča).

Čarniaŭka (r.) - Czerniawka, oznaczony na mapie Pachołowieckiego jako Oskaczi$c z a$ (Skacica) lewy dopływ rzeki Obol $(\rightarrow$ Obaĺ). Wypływa z jeziora Czernowo (Čarnova) i uchodzi do rzeki Obol w wiosce Skatica.

Čarnica (m.) ${ }^{\star}$ - Czernica, nieistniejąca dziś osada nad rzeką o tej nazwie, prawym dopływem rzeki Budowieść (Budaviesć) ${ }^{18}$ B. 
Čarnica (r.) - Czernica, lewy dopływ Berezyny ( $\rightarrow$ Biarezina), do której uchodzi nieopodal wsi Bierazino, około $90 \mathrm{~km}$ na południowy zachód od Połocka.

Čarnievičy - Czerniewicze, osada nad rzeką Auta (Avuta), prawym dopływem Dzisny ( $\rightarrow$ Dzisna), około $50 \mathrm{~km}$ na południowy zachód od Połocka ${ }^{15 \mathrm{~B}}$.

Čašniki - Czaśniki, miasteczko i zamek nad rzeką Ułłą (Ula), około $80 \mathrm{~km}$ na południowy zachód od Witebska ( $\rightarrow$ Vicebsk). Pod Czaśnikami miały miejsce dwie ważne batalie wojen inflanckich, związane z próbami odbicia Połocka z rąk moskiewskich: 26 stycznia 1564 roku litewska armia hetmanów Mikołaja Radziwiłła Rudego i Grzegorza Chodkiewicza rozbiła wojska kniaziów Wasyla Sieriebriannego-Oboleńskiego i Piotra Szujskiego, zaś 20 lipca 1567 roku wojewoda bracławski Roman Sanguszko pokonał wojska moskiewskie pod komendą kniazia Piotra Sieriebriannego ${ }^{26 \mathrm{~B}}$.

Cierbiašova - Terbiaszowo, osada na prawym brzegu Dźwiny, około $30 \mathrm{~km}$ na zachód od Witebska $(\rightarrow \text { Vicebsk })^{27}$.

Ciotča - Ciotcza, zamek pomiędzy jeziorami Ciotcza (Ciotča, także Paule Paŭlskaje) i Berezowskim (Biarozaŭskaje), około $40 \mathrm{~km}$ na południowy wschód od Połocka. Zamek został zdobyty i zniszczony przez wojska litewskie w grudniu 1569 roku: odbudowano go przy jeziorze Ciotcza w miejscu, z którego widoczna była droga moskiewska. W pobliżu zlokalizowany był również zamek Krasne $\left.(\rightarrow \text { Krasny })^{\star}\right)^{16 \Gamma}$.

Domniki - osada około $30 \mathrm{~km}$ na wschód od Połocka, na prawym brzegu rzeki Sośnicy (Sosnica) $)^{17 \mathrm{~A}}$.

Druja - obronna miejscowość z drewnianym zamkiem u ujścia rzeki Drujki $\left(\rightarrow\right.$ Drujka) do Dźwiny, około $100 \mathrm{~km}$ na północny zachód od Połocka ${ }^{55}$.

Drujka (r.) - lewy dopływ Dźwiny (52 km biegu), wypływa z jeziora Drywiaty (Dryviaty), uchodzi w miejscowości $\rightarrow$ Druja.

Drysa (r.) - Dryssa, prawy dopływ Dźwiny (183 km biegu) wypływający z jeziora Dryssy, ujście w północnej części dzisiejszego miasta Wierchniedźwińsk $(\rightarrow$ Vierchniadzvinsk).

Dzisna (m.) - miasto u ujścia rzeki o tej nazwie do Dźwiny, około $40 \mathrm{~km}$ na północny zachód od Połocka. Po utracie Połocka w 1563 roku Zygmunt II August zbudował na wyspie pośrodku Dźwiny zamek, umocniony następnie przez Stefana Batorego. 4 sierpnia 1579 roku Batory odebrał w Dziśnie hołd od księcia Kurlandii Gottharda Kettlera, zaś dzień później armia polsko-litewska, sforsowawszy Dźwinę, ruszyła na Połock ${ }^{15 \mathrm{~A}}$. 
Dzisna (r.) - lewy dopływ rzeki Dźwiny (178 km długości), wypływa z jeziora Dzisna (Dysnai) na Litwie, ujście w miejscowości $\rightarrow$ Dzisna (m.).

Dzvina (r.) - Dźwina, główna spławna rzeka Połocczyzny i Inflant $(1020 \mathrm{~km}$ długości), przepływa między innymi przez Witebsk, Połock, Dyneburg i Rygę; źródło na Wyżynie Wałdajskiej w Rosji, ujście do Bałtyku w Rydze.

Halomysi ${ }^{\star}$ - miejscowości Hołomyśl nie udało się zidentyfikować w rejonie, w którym umieszcza ją Pachołowiecki, to jest na lewym brzegu Dźwiny na zachód / południowy zachód od Suraża ( $\rightarrow$ Suraž). Osada Hołomyśl (ros. Holomysl', białorus. Halomysla) istnieje, ale nad rzeką $\rightarrow$ Dzisna, około $10 \mathrm{~km}$ na południowy zachód od jej ujścia do Dźwiny.

Halubičy - Hołubicze, osada około $20 \mathrm{~km}$ na wschód od m. Głębokie ( $\rightarrow$ Hlybokaje) i około $90 \mathrm{~km}$ na południowy zachód od Połocka ${ }^{23}$.

Haradok - Horodek, miasto około $30 \mathrm{~km}$ na północ od Witebska ( $\rightarrow$ Vicebsk) nad rzeką Usysą, pograniczna twierdza Wielkiego Księstwa Litewskiego, od końca XVI wieku posiadająca ufortyfikowany zamek ${ }^{18}$.

Harany - Horany, osada nieopodal ujścia rzeki Obol $(\rightarrow$ Obaĺ) do Dźwiny, około $17 \mathrm{~km}$ na południowy wschód od Połocka ${ }^{17 \mathrm{~B}}$.

Hermanavičy - Hermanowicze, osada nad rzeką $\rightarrow$ Dzisna, niespełna $80 \mathrm{~km}$ na zachód od Połocka ${ }^{14}$.

Hlybokaje - Głębokie, miasteczko nad jeziorem Wielkie (Vialikaje), około $85 \mathrm{~km}$ na południowy zachód od Połocka, założone w 1414 roku przy trakcie z Wilna, spustoszone i zajęte w 1563 roku przez wojska moskiewskie, odbite przez Batorego w czasie marszu na Połock ${ }^{23 \mathrm{~A}}$.

Ikazń - Ikaźń, osada nad jeziorem o tej nazwie, 15 km na wschód od Brasławia $(\rightarrow \text { Braslaŭ })^{135}$.

Jazna - Jazno, osada między jeziorami Małe i Wielkie Jazno (Maloje Jazna, Vialikaje Jazna), niespełna $50 \mathrm{~km}$ na zachód od Połocka ${ }^{15 \text { в }}$.

Jeziaryšča - Jezieryszcze, także Ozieryszcze, pograniczna twierdza Wielkiego Księstwa Litewskiego około $80 \mathrm{~km}$ na północ od Witebska ( $\rightarrow$ Vicebsk), nad jeziorem o tej nazwie, zdobyta w listopadzie 1564 roku przez wojska Iwana IV Groźnego, odzyskana przez Batorego jesienią 1580 roku $^{10}$.

Kaliucina $^{*}$ - oznaczona na mapie Pachołowieckiego jako kieluta odpowiada zapewne nieistniejącej dziś osadzie Kolucino około $50 \mathrm{~km}$ na północ od Połocka. Wymieniona w rejestrze carskich nadań ziemskich (поместьей) z 1572 
roku jako „пустошь Калютино” we włości Nieszczerda (zob. Иван Грозный завоеватель Полоцка, s. 85).

Kamień - osada około $55 \mathrm{~km}$ na południe od Połocka ${ }^{25}$.

Kasplia (r.) - Kaspla, oznaczona na mapie jako Surazicza, lewy dopływ Dźwiny (136 km długości), wypływa z jeziora Kaspla (Kasplia) w Rosji, ujście w Surażu $(\rightarrow$ Suraž) .

Kaziany - Koziany, zamek nad rzeką Obol ( $\rightarrow$ Obaĺ), około 60 km na północny zachód od Połocka. Twierdza, której pozostałości znajdują się w zakolu rzeki na północ od przysiółka Krasnomaj, wzniesiona została w 1563 roku przez Iwana IV Groźnego i zdobyta przez kozaków litewskich hetmana Krzysztofa Radziwiłła 23 lipca $1579 \mathrm{roku}^{18 \mathrm{~A}}$.

Krasny $^{\star}$ - Krasne, zamek około $40 \mathrm{~km}$ na południowy wschód od Połocka, zbudowany w 1564 roku na rozkaz Zygmunta II Augusta, wkrótce jednak zdobyty przez wojska moskiewskie. 31 lipca 1579 roku twierdzę opanowali kozacy litewscy pod komendą Franciszka Żuka, ale dzień później odbiła ją i spaliła wezwana na pomoc moskiewska załoga zamku Susza ( $\rightarrow$ Suša). Sporne jest położenie twierdzy: mogła wznosić się na brzegu jeziora Berezowskiego (Biarozaŭskaje) nieopodal wsi Krasnaje, względnie na terenie wsi Ciotcza ( $\rightarrow$ Ciotča) lub wreszcie na północ od wsi Krasnaja Horka między jeziorami Plesno (Pliesna) i Ostrowito (Astravita) ${ }^{16 \mathrm{r}, 25 \mathrm{~b}}$.

Krywinka (r.) - Krywina, lewy dopływ Dźwiny (34 km długości), wypływa z jeziora Bogdanowskiego (Bagdanaŭskaje), ujście we wsi Chmielnik (Chmiaĺnik) nieopodal miejscowości Bieszenkowicze (Biešankovičy), około $50 \mathrm{~km}$ na południowy zachód od Witebska ( $\rightarrow$ Vicebsk).

Losvida - Łoswido, osada (dzis. Wialikaje Losvida) nad jeziorem o tej samej nazwie, około $30 \mathrm{~km}$ na północ od Witebska $(\rightarrow \text { Vicebsk })^{18 \Gamma}$.

Loŭža - Łowoż, osada nad jeziorem o tej nazwie (część dzisiejszej wsi Pabieda), w połowie drogi pomiędzy Witebskiem $\left(\rightarrow\right.$ Vicebsk) a Połockiem ${ }^{17 \Gamma}$.

Lučosa (r.) - Łuczesa, oznaczony na mapie Pachołowieckiego jako Ruczai lewy dopływ Dźwiny (90 km długości), wypływa z jeziora Zielianskoje, ujście na południowych peryferiach dzisiejszego Witebska ( $\rightarrow$ Vicebsk).

Lukomí - Łukoml, osada nad jeziorem Łukomskim (Lukomskaje) około $100 \mathrm{~km}$ na południe od Połocka, $20 \mathrm{~km}$ od Czaśnik ( $\rightarrow$ Čašniki). Istniejący od XIV wieku pograniczny zamek Wielkiego Księstwa Litewskiego został zniszczony w 1563 roku przez wojska moskiewskie ${ }^{32}$. 
Lužasna - Łużasna, osada obronna na prawym brzegu Dźwiny, około $10 \mathrm{~km}$ na północ od Witebska ( $\rightarrow$ Vicebsk $)^{19 \mathrm{~B}}$.

Maly Haradok ${ }^{\star}$ - nieistniejąca dziś osada pod Horodkiem ( $\rightarrow$ Haradok), wzmiankowana po raz pierwszy na mapie Pachołowieckiego.

Maryniec $^{\star}$ - nieistniejąca dziś osada nad potokiem o tej nazwie, prawym dopływem rzeką Obol ( $\rightarrow$ Obal), ujście na terenie wsi Tupiczyno (Tupičyna).

Miĺkavičy - Milkowicze, osada na lewym brzegu Dźwiny, około $50 \mathrm{~km}$ na południowy zachód od Witebska ( $\rightarrow$ Vicebsk) ${ }^{27 \mathrm{~A}}$.

Nieščarda* - Nieszczerda, nieistniejąca dziś warownia położona prawdopodobnie na południowym brzegu jeziora Nieszczerdo (Nieščarda) około $50 \mathrm{~km}$ na północ od Połocka, wzniesiona około 1563 roku przez Iwana IV Groźnego i zdobyta 13 grudnia 1579 roku przez Mikołaja Dorohostajskiego.

Nišča (r.) - Niszcza, prawy dopływ Dryssy ( $\rightarrow$ Drysa), 85 km długości, wypływa z jeziora Niszcza około $80 \mathrm{~km}$ na północ od Połocka. U jej ujścia, na zachód od wsi Kulniewo (Kuĺnieva), wznosił się zamek Sokół ( $\rightarrow$ Sokal).

Obal (r.) - Obol, jeden z większych prawych dopływów Dźwiny (148km biegu), wypływa z jeziora Jezieryszcze (Jeziaryšča), uchodzi poniżej dzisiejszej wsi Nowe Horany (Novyja Harany).

Obal (voz.) - Obol, jezioro utworzone przez rzekę o tej nazwie w jej górnym biegu, około $70 \mathrm{~km}$ na północny wschód od Połocka ${ }^{18 \mathrm{~A}}$.

Pahost - Pohost, osada (dzisiejszy Novy Pahost) około $40 \mathrm{~km}$ na południowy wschód od Brasławia $(\rightarrow \text { Braslaŭ })^{13 \text { Б }}$.

Palata (r.) - Połota, prawy dopływ Dźwiny (93 km długości), wypływa z jeziora Kołpino (Kolpino) na terenie Rosji, ujście w Połocku.

Plisa - osada nad jeziorem o tej nazwie, około $70 \mathrm{~km}$ na południowy zachód od Połocka ${ }^{14}$. .

Polack - Połock, miasto u ujścia Połoty do Dźwiny, jeden z najstarszych ośrodków Rusi Kijowskiej. Pierwszym znanym z imienia władcą Połocka był Rogwołod, któremu w drugiej połowie X wieku udało się na krótko uniezależnić od Rurykowiczów kijowskich i książąt nowogrodzkich. Około 977-978 roku przyłączony do Rusi przez Włodzimierza Wielkiego. Następnie około 988 roku przekazany synowi Włodzimierza, Izjasławowi (zm. 1001), założycielowi dynastii Rogwołodowiczów połockich (Izjasławiczów). Dynastia ta wygasła w XIII wieku. W 1392 roku księstwo włączono do Wielkiego Księstwa Litewskiego, a w 1504 utworzono województwo połockie. Księstwo „reaktywował” Iwan IV Groźny, który po 
zdobyciu miasta 15 lutego 1563 roku przyjął tytuł księcia połockiego. Po odzyskaniu Połocka przez Stefana Batorego miasto stało jednym z ważniejszych ośrodków politycznych, gospodarczych, religijnych i kulturalnych Wielkiego Księstwa Litewskiego. Mapa Księstwa Połockiego, a zwłaszcza zamieszczony na niej łaciński „biogram” Połocka, to część swoistej propagandy „Ziem Odzyskanych", mającej na celu uzasadnienie wyprawy połockiej prawami wielkich książąt litewskich do dawnego księstwa. Zob. G. Franczak, Polotia recepta. Mapa Księstwa Połockiego jako tekst propagandowy (w przygotowaniu) ${ }^{16 \text { АБвг }}$.

Psuja - osada nad jeziorem o tej nazwie, około $60 \mathrm{~km}$ na południowy zachód od Połocka ${ }^{24 \mathrm{~A}}$.

Roŭnaje - Równe, osada około 50 km na wschód od Połocka, między jeziorami Kanaplianka i Tennica ${ }^{17 \Gamma}$.

Sianno - Sienno, miasteczko nad jeziorem o tej nazwie, około $60 \mathrm{~km}$ na południowy zachód od Witebska ( $\rightarrow$ Vicebsk), zniszczone przez wojska moskiewskie w czasie wojny litewsko-rosyjskiej w latach 1534-1537, następnie odbudowane i umocnione $\mathrm{e}^{27}$.

Siebiež - Siebież, warownia nad jeziorem Siebieskim (Siebiežskoje), zbudowana w 1535 roku przez Rosjan dla obrony szlaku pskowsko-połockiego, zdobyta przez wojska Batorego w 1579 roku i zwrócona państwu moskiewskiemu na mocy rozejmu w Jamie Zapolskim (1582). Dziś w obwodzie pskowskim Federacji Rosyjskiej.

Sitna - Sitno, zamek zbudowany przez Iwana IV Groźnego około 1566 roku nad jeziorem Izmok (Izmak), w zakolu wypływającej zeń Połoty ( $\rightarrow$ Palata), na terenie dzisiejszej wsi Maloje Sitna około $60 \mathrm{~km}$ na północny wschód od Połocka. Został zdobyty i spalony przez wojska Batorego 4 sierpnia 1579 roku $^{175}$.

Šo - Szo, dawniej Szosza (Šoša), osada nad jeziorem o tej nazwie ${ }^{24 \mathrm{~A}}$.

Sokal - Sokól, twierdza u ujścia Niszczy ( $\rightarrow$ Nišča) do Dryssy $(\rightarrow$ Drysa) - jej pozostałości znajdują się na zachód od dzisiejszej wsi Kulniewo (Kuĺnieva). Zbudowana w 1566 roku przez Iwana IV Groźnego, została zdobyta i spalona 2 września 1579 roku przez wojska polsko-litewskie pod komendą Mikołaja Mieleckiego ${ }^{7 \Gamma}$. Soržyca - osada Sorżyca nad jeziorem Ostrowieńskim (Astrovienskaje) połączonym z jeziorem Soro, około $40 \mathrm{~km}$ na południowy zachód od Witebska $(\rightarrow \mathbf{V i -}$ cebsk) ${ }^{27 \mathrm{~A}}$.

Staroje Sialo - Stare Sioło, osada na prawym brzegu Dźwiny, około $23 \mathrm{~km}$ na zachód od Witebska $(\rightarrow \text { Vicebsk })^{27}$. 
Stary Liepiel̂ - dawniej Lepel, miasteczko $70 \mathrm{~km}$ na południe od Połocka, nad jeziorem Lepelskim (Liepieĺskaje). W latach 1558-1563 na wyspie na jeziorze powstał zamek, zdobyty i spalony w 1563 roku przez wojska moskiewskie, wkrótce potem odbity przez Mikołaja Radziwiłła Rudego 25 в

Stryžava - Stryżewo, osada nad jeziorem Słobodzkie (Slabadskoje) i przepływającą przezeń rzeką Świeczą ( $\rightarrow$ Sviača), około $60 \mathrm{~km}$ na zachód od Witebska $(\rightarrow$ Vicebsk) i $18 \mathrm{~km}$ na południe od miasta Ułła ( $\rightarrow$ Ula). Pomyłka kartografa bądź rytownika polega na błędnym umieszczeniu toponimu przy lewym zamiast przy prawym dopływie rz. Ułły, gdzie wyrytowano miejscowość bez nazwy ${ }^{26}$ Б.

Suraž - Suraż, miasteczko u ujścia rzeki Kaspli ( $\rightarrow$ Kasplia) do Dźwiny, około 40 km na północny wschód od Witebska ( $\rightarrow$ Vicebsk), z drewnianym zamkiem zbudowanym na rozkaz Zygmunta II Augusta w 1563 roku przez wojewodę witebskiego Stefana Zbaraskiego ${ }^{20 ~ B}$.

Suša - Susza, zamek na przesmyku dzielącym jezioro Temenica (Ciemienica ) od jeziora Ostrowki (Astraŭki), między dzisiejszymi wioskami Susza (Suša) i Dwór Susza (Dvor Suša), około $50 \mathrm{~km}$ na południowy wschód od Połocka, zbudowany w 1566 roku na rozkaz Iwana IV Groźnego przez kniazia Jurija Tokmanowa. Twierdza poddała się wojskom polsko-litewskim dopiero 6 października 1579 $\operatorname{roku}^{25 \mathrm{~b}}$.

Sviača (r.) - Świecza, prawy dopływ rzeki Ułły, do której uchodzi nieopodal wsi Dybali, około $60 \mathrm{~km}$ na południowy wschód od Połocka.

Svirydavičy $^{\star}$ - nieistniejąca dziś osada Swirydowicze nieopodal miejscowości Jezieryszcze ( $\rightarrow$ Jeziaryšča). Wymieniona w rejestrze carskich nadań ziemskich (поместьей) z 1572 roku jako „пустошь что было село Сваридовичи на ръкъ на Сваридовке” we włości Jezieryszcze (zob. Иван Грозныц - завоеватель Полоцка, s. 106-107).

Turaspollie - Turospol, osada na zachód od jeziora Krzywe (Kryvoje), około 50 km na południe od Połocka ${ }^{25}$ Б

Turoŭlia - Turowla, nieistniejąca dziś twierdza u ujścia rzeki Turowlanki (Turaŭlianka) do Dźwiny, około $20 \mathrm{~km}$ na południowy wschód od Połocka (dzisiejsze Haradzišča), zbudowana przez Iwana IV Groźnego w 1566 roku, zajęta bez walki 4 września 1579 roku przez wojska polsko-litewskie pod komendą Konstantego Łukomskiego i Marcina Kurcza ${ }^{16 \Gamma}$.

Ula - Ułła, miasteczko u ujścia rzeki o tej samej nazwie do Dźwiny, około $50 \mathrm{~km}$ na południowy wschód od Połocka. Po upadku Połocka w 1563 roku Zygmunt II 
August rozpoczął budowę zamku na półwyspie między Ułłą i Dźwiną. Wkrótce miasto wpadło w ręce Iwana IV Groźnego, który około 1566 roku wzniósł tam drewniano-ziemną fortecę, zdobytą następnie, we wrześniu 1568 roku, przez hetmana polnego litewskiego Romana Sanguszkę. Twierdza, umocniona w 1580 roku na rozkaz Batorego, nie dochowała się do naszych czasów: spłonęła w czasie wojny polsko-rosyjskiej w $1654 \mathrm{roku}^{17 \mathrm{~B}}$.

Ušača (r./m.) - Uszacz, lewy dopływ Dźwiny (długość $118 \mathrm{~km}$ ), wypływa niedaleko wsi Puciłkowicze (Pucilkavičy) około $80 \mathrm{~km}$ na południe od Połocka, ujście w zachodniej części dzisiejszego Nowopołocka (Navapolack), na którego terenie musiałaby się znajdować Vsacza oznaczona na mapie Pachołowieckiego jako miejscowość.

Usviaty - Uświat, miasto nad rzeką Uświatą ( $\rightarrow$ Uśviača) i jeziorem Uświat (Usviatskoje), dziś w obwodzie pskowskim Federacji Rosyjskiej, pograniczna twierdza Wielkiego Księstwa Litewskiego w czasach Olgierda i Witolda, zajęta przez Iwana IV Groźnego w 1566 roku, odbita przez wojska Jana Zamoyskiego w 1580 roku.

Uśviača (r.) - Uświata, prawy dopływ Dźwiny (100 km długości), wypływa z jeziora Horodośne (Ordosno) w obwodzie pskowskim, ujście naprzeciw Suraża $(\rightarrow$ Suraž). Nazwa Vswiaczicza pojawiająca się na mapie Pachołowieckiego wskazywałaby mylnie na prawy dopływ tej rzeki - Uświatycę czy Owsianicę (Aŭsianka).

Varoničy - Woroniecz, osada nad rzeką Uszacz ( $\rightarrow$ Ušača), między jeziorami Woroniecz (Varonieč) i Brody (Barody), około $20 \mathrm{~km}$ na południowy zachód od Połocka. W 1563 roku zajęta przez Iwana IV Groźnego, wkrótce odzyskana. W 1566 roku horodniczy połocki Franciszek Żuk zbudował zamek (do dziś zachowały się umocnienia ziemne), który czynił z Woroniecza jedną z ważniejszych placówek militarnych tej części Połocczyzny ${ }^{16 \mathrm{~B}}$.

Viata - Wiata, osada na lewym brzegu Dźwiny, około 90 km na północny zachód od Połocka ${ }^{6 \mathrm{~B}}$.

Viažyšča - Wiażyszcze, osada na lewym brzegu rzeki Dźwiny, około 35 km na południowy zachód od Witebska ( $\rightarrow$ Vicebsk $)^{27 \text { A }}$.

Vicebsk - Witebsk, miasto na szlaku znad Bałtyku do Konstantynopola, u ujścia rzek Widźby ( $\rightarrow$ Vićba) i Łuczesy ( $\rightarrow$ Lučosa) do Dźwiny, do 1021 roku we władaniu książąt kijowskich, następnie w składzie Księstwa Połockiego (do 1101 roku), stolica udzielnego Księstwa Witebskiego do 1320 roku, kiedy to księ- 
ciem witebskim został wielki książę litewski Olgierd, by wkrótce przyłączyć ziemię witebską do Litwy. Stolica województwa od 1503 roku, pomimo częstych oblężeń (najcięższe w 1563 roku, kiedy wojska Iwana IV Groźnego spaliły znaczną część miasta), Witebsk pozostawał w czasie wojen inflanckich ważną i niezdobytą twierdzą litewską na granicy z Moskwą ${ }^{28 \text { AB }}$.

Vićba (r.) - Widźba, lewy dopływ Dźwiny (33km biegu), do której uchodzi w Witebsku ( $\rightarrow$ Vicebsk).

Vierchniadzvinsk - Wierchniedźwińsk, dawniej Dryssa, miasto u ujścia rzeki Dryssy ( $\rightarrow$ Drysa) do Dźwiny, pograniczna twierdza Wielkiego Księstwa Litewskiego z zamkiem zbudowanym przez wojewodę połockiego Stanisława Dowojnę około 1546 roku, bezskutecznie oblegana przez wojska moskiewskie w czasie wojen inflanckich $1558-1582^{6}$.

Viesnick - Wiestnick, osada około $60 \mathrm{~km}$ na południowy zachód od Połocka i około $25 \mathrm{~km}$ od miejscowości Uszacz (Ušačy) ${ }^{24}$.

Voskata - Oskato, osada około $80 \mathrm{~km}$ na wschód od Połocka, nad rzeką Czerniawką $(\rightarrow \text { Čarniaŭka, być może dawna nazwa Oskacica })^{18}$.

Zaborje - Zaborze, około $70 \mathrm{~km}$ na południowy zachód od Połocka i około $20 \mathrm{~km}$ na północny wschód od miejscowości Głębokie $(\rightarrow \text { Hlybokaje })^{23}$ Б .

Zaviačellie - Zaweczele, osada około $40 \mathrm{~km}$ na południe od Połocka i na wschód od jeziora Weczele (Viačellie) ${ }^{25 \mathrm{~A}}$. 


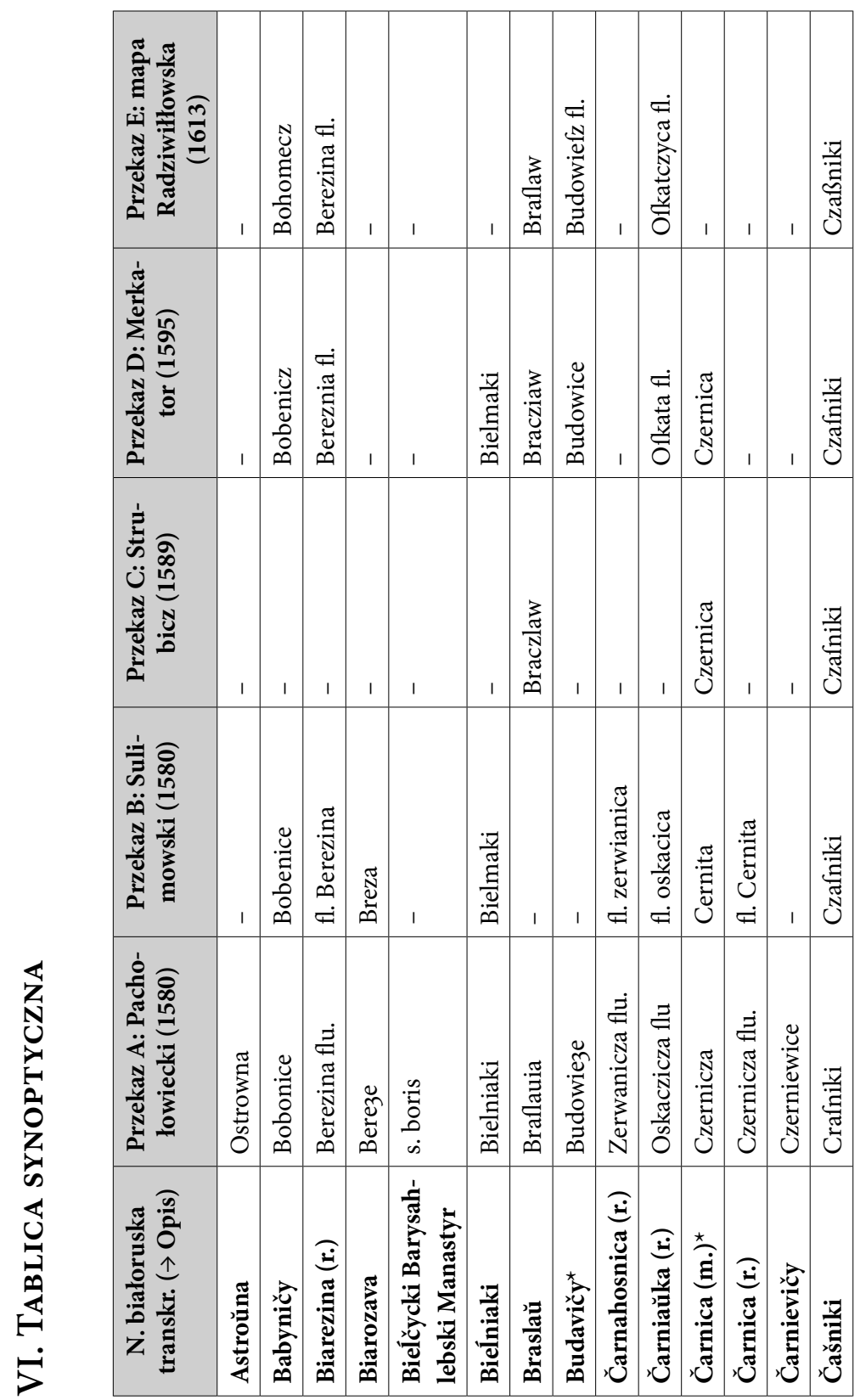




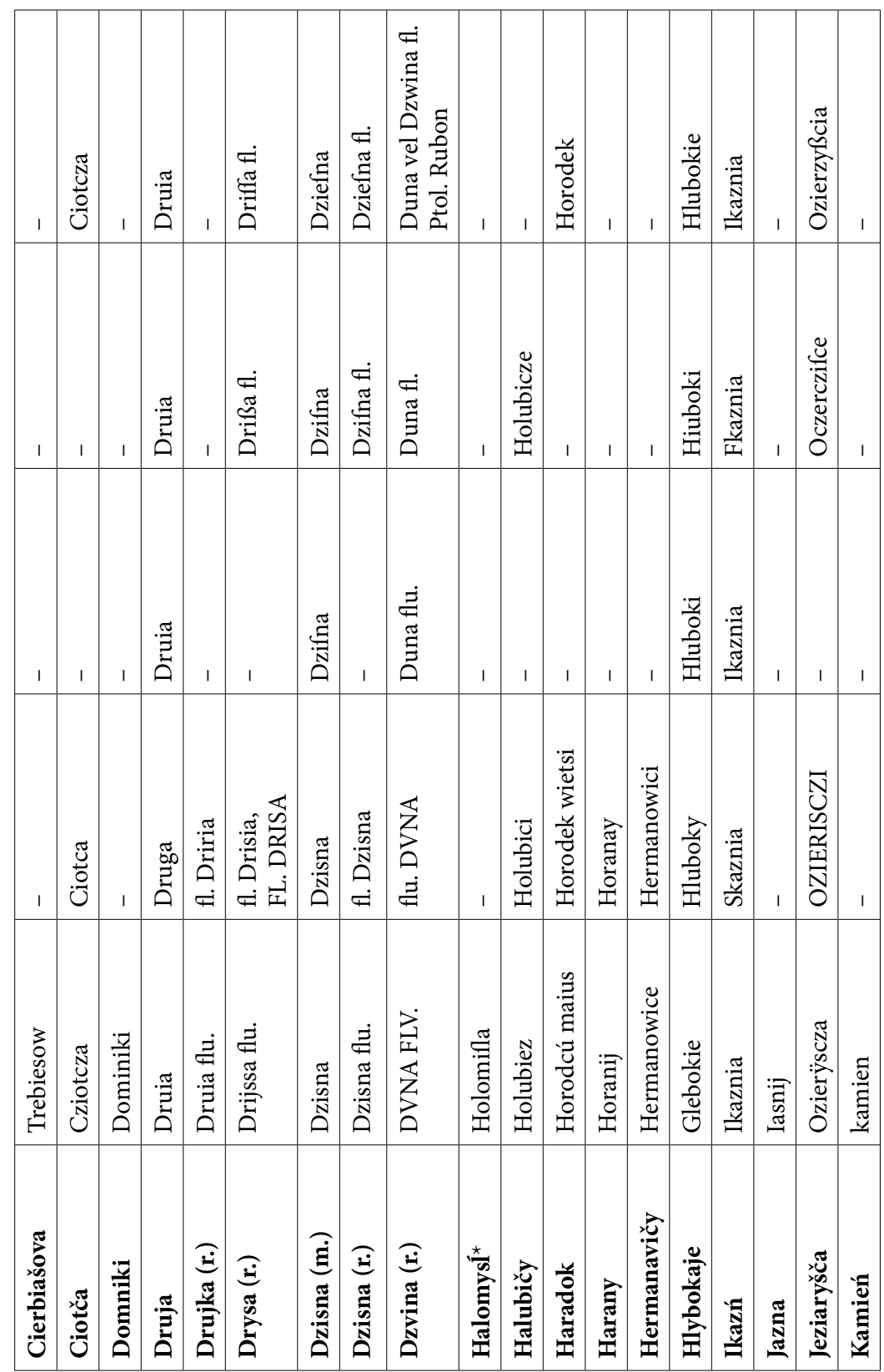




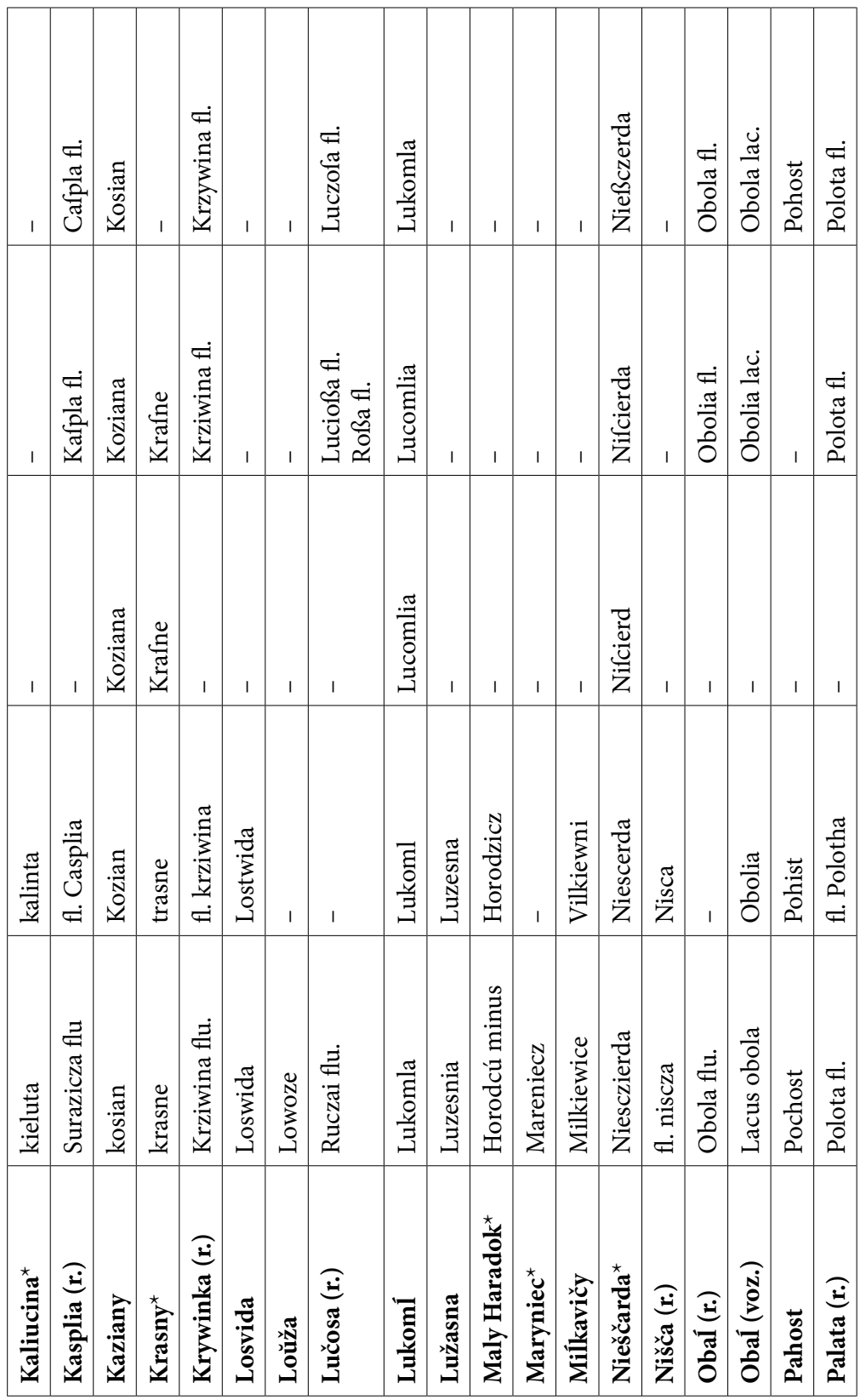




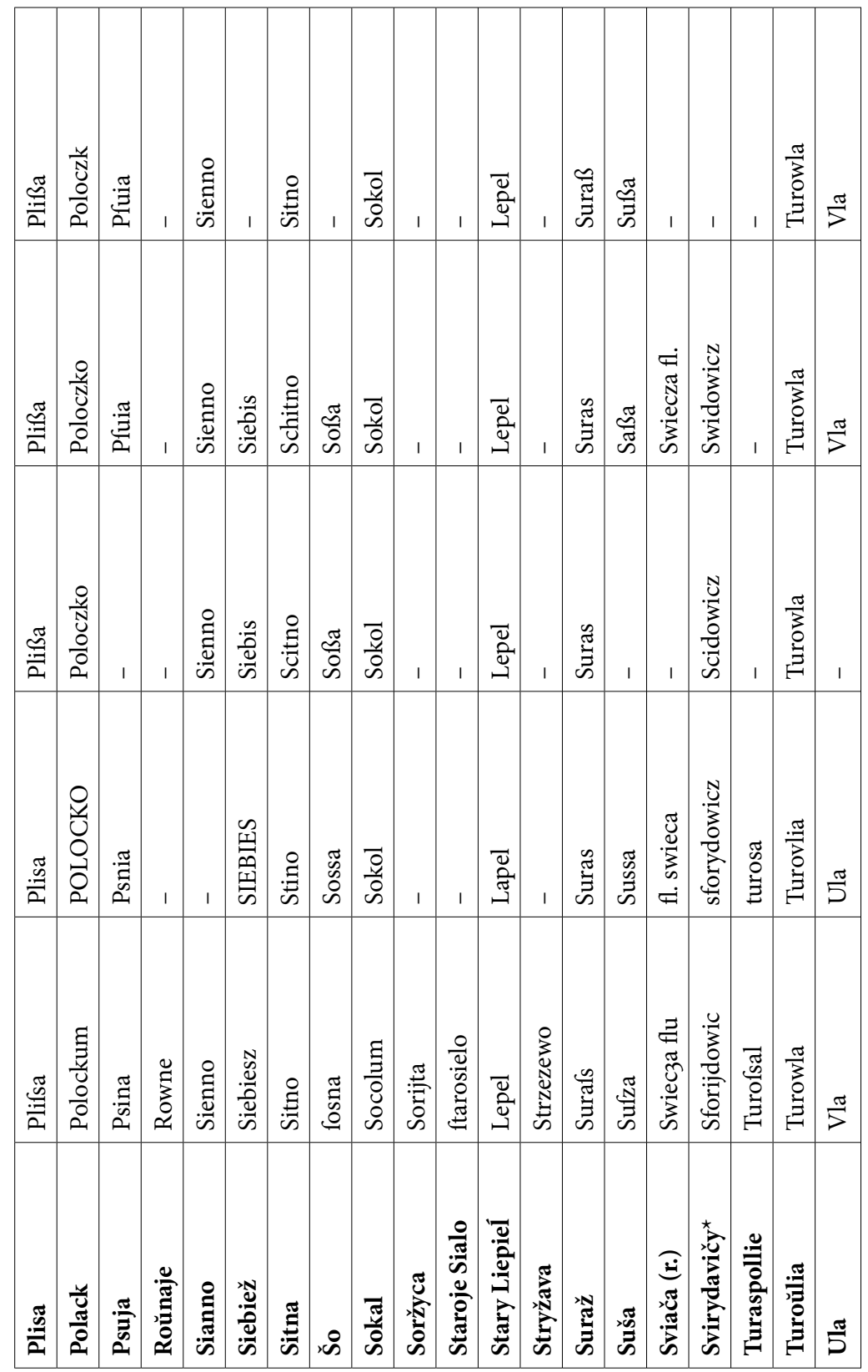




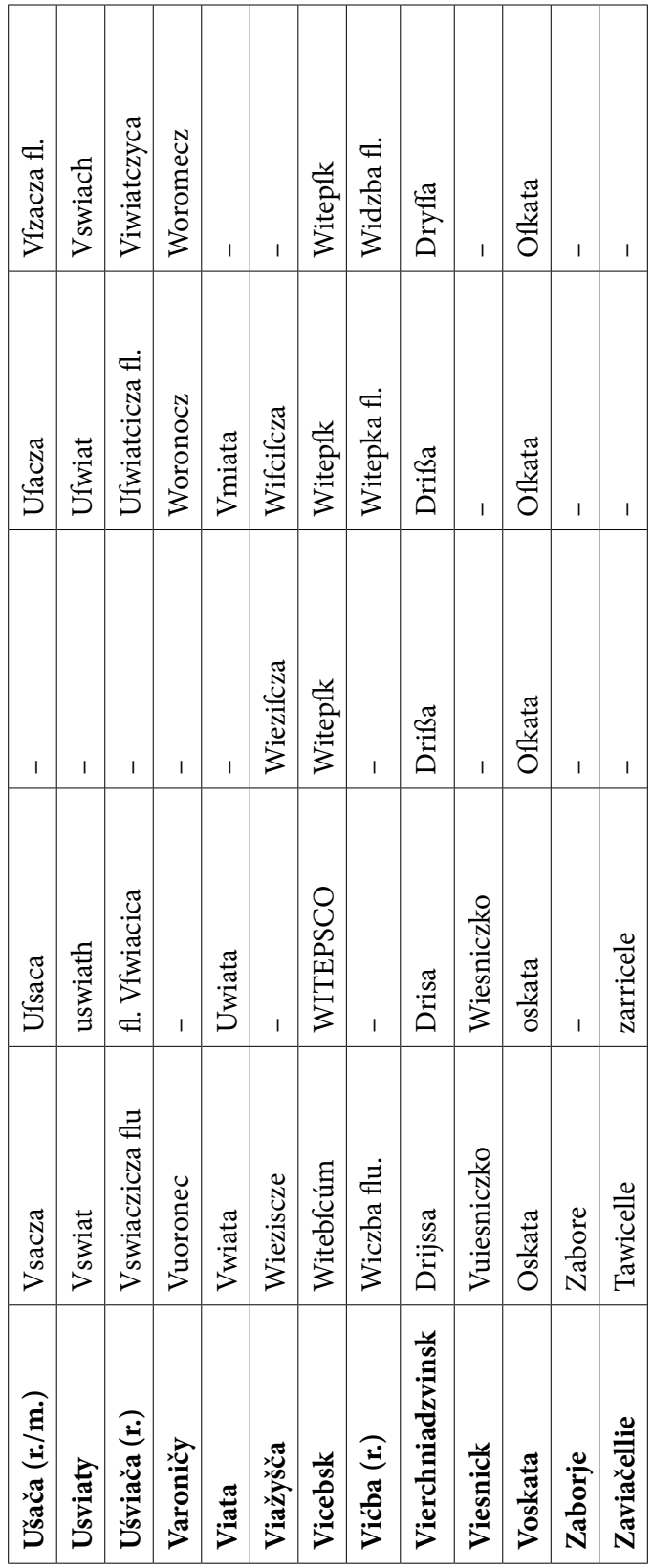

